OPEN ACCESS

Edited by:

Erik Olsen,

Norwegian Institute of Marine

Research (IMR), Norway

Reviewed by:

Miguel Dino Fortes,

University of the Philippines Diliman,

Philippines

Andrew Kenny,

Centre for Environment, Fisheries

and Aquaculture Science (CEFAS),

United Kingdom

*Correspondence:

Carolyn J. Lundquist

carolyn.lundquist@niwa.co.nz

${ }^{+}$Present address:

Kathryn K. Davies,

University of Utah, Salt Lake City, UT, United States

Melissa Foley,

San Francisco Estuary Institute,

Richmond, VA, United States

Specialty section:

This article was submitted to

Global Change and the Future Ocean,

a section of the journal

Frontiers in Marine Science

Received: 01 May 2019

Accepted: 14 January 2020

Published: 18 February 2020

Citation:

Davies KK, Fisher KT, Couzens G,

Allison A, van Putten El,

Dambacher JM, Foley M and

Lundquist CJ (2020) Trans-Tasman

Cumulative Effects Management:

A Comparative Study.

Front. Mar. Sci. 7:25

doi: 10.3389/fmars.2020.00025

\section{Trans-Tasman Cumulative Effects Management: A Comparative Study}

\author{
Kathryn K. Davies ${ }^{1+}$, Karen T. Fisher ${ }^{2}$, Gemma Couzens ${ }^{3}$, Andrew Allison ${ }^{1,2,4}$, \\ Elizabeth Ingrid van Putten ${ }^{5,6}$, Jeffrey M. Dambacher ${ }^{5}$, Melissa Foley ${ }^{7 \dagger}$ and \\ Carolyn J. Lundquist ${ }^{1,4 *}$
}

\begin{abstract}
${ }^{1}$ National Institute of Water and Atmospheric Research, Hamilton, New Zealand, ${ }^{2}$ School of Environment, The University of Auckland, Auckland, New Zealand, ${ }^{3}$ Ministry for the Environment, Wellington, New Zealand, ${ }^{4}$ Institute of Marine Science, The University of Auckland, Auckland, New Zealand, ${ }^{5}$ Oceans and Atmosphere, Commonwealth Scientific and Industrial Research Organisation, Hobart, TAS, Australia, ${ }^{6}$ Centre for Marine Socioecology, University of Tasmania, Hobart, TAS, Australia, ${ }^{7}$ Research and Evaluation Unit, Auckland Council, Auckland, New Zealand
\end{abstract}

Managing the cumulative effects (CE) that arise from human and natural stressors is one of the most urgent and complex problems facing coastal and marine decision makers today. In the absence of effective processes, models, and political will, decisionmakers struggle to implement management strategies that effectively tackle cumulative effects. Emerging efforts to address cumulative effects provide a timely opportunity to assess the efficacy of a range of management strategies operating at different scales and in different legislative and cultural contexts. Using primarily qualitative methodologies including literature reviews, focus groups, and workshops, this paper compares cumulative effects approaches within the Reef 2050 Plan for the Great Barrier Reef Marine Park (GBRMP), Australia, with those in Aotearoa New Zealand (Aotearoa NZ). Both case studies illustrate that cumulative effects management is especially complicated by: fragmented legislative regimes and institutions that cannot account for cross-scale or cross-sector interactions; chronic data scarcity and high levels of uncertainty that make system-based assessments and predictions challenging; and often conflicting societal and economic expectations, values, and rights that are poorly integrated into management decision-making. By considering how these two cases align with transformational change characteristics, we draw several conclusions and establish priority actions regarding (1) how to mobilise resources and political will to address CE, (2) how to deal with data scarcity and uncertainty, and (3) how to promote comprehensive and inclusive CE management of coastal and marine areas.

Keywords: Aotearoa, Australia, cumulative effects, cumulative impacts, ecosystem-based management, governance, Great Barrier Reef, New Zealand

\section{INTRODUCTION}

Managing for cumulative effects (CE) in coastal and marine systems is confounded by many issues operating across a variety of spatial and temporal scales. There is a general recognition that collaboration between key institutes and stakeholders is needed to produce successful CE governance and management (Halpern and Fujita, 2013; Murray et al., 2014; Mach et al., 2015; Lundquist et al., 2016), but there is little discussion of the aspirational or negotiated elements 
of the relationships between institutes and stakeholders required to develop common visions for CE management. Meanwhile ongoing degradation of marine environments resulting from the inadequate management of $\mathrm{CE}$ has led to the degradation or loss of resources (Foley et al., 2017), and created uncertainty for investors (Davies et al., 2018a). To adequately respond to $\mathrm{CE}$, a more strategic approach is needed that considers, and where possible aligns, legislative frameworks and institutional practices, data collection and assessment, and consideration of values and rights in decision making across multiple scales and sectors (Le Heron et al., 2016).

For the purposes of our research, and in light of the myriad definitions of cumulative effects (or cumulative impacts) in international research, we define CE here as the effects of stressors that overlap in space and/or time (e.g., caused by a single repeated stressor or multiple stressors) (Davies et al., 2018a). This high-level definition, we argue, provides us enough clarity and flexibility to guide the cross-boundary discussions that are needed to address CE management in coastal and marine areas. Moreover, we distinguish $\mathrm{CE}$ assessment from $\mathrm{CE}$ management; while assessment of CE is becoming increasingly common in human-environmental systems (Halpern et al., 2015; Korpinen and Andersen, 2016; Stelzenmüller et al., 2018), $\mathrm{CE}$ assessment is often tenuously linked to, and does not necessarily instigate, $\mathrm{CE}$ management of coastal and marine systems (Stelzenmüller et al., 2018).

Reviews of CE suggest three key challenges to the implementation of CE management: (1) fragmented legislative regimes, which makes consideration of multi-scale interactions difficult (Therivel and Ross, 2007; Canter and Ross, 2010); (2) a lack of standardised, long-term ecological-scale data and modelling capability, which makes system-based assessments and predictions challenging to undertake (Sheaves et al., 2016); and (3) poor integration of socio-economic and cultural values, and Indigenous rights into management decision-making, which can lead to short-term planning horizons and high levels of conflict (Goldberg et al., 2016). One study identified a shared vision, the capacity to work across institutions, and a set of national scale guidelines as some of the perceived key transformative elements needed to effectively address CE in Aotearoa New Zealand (Aotearoa NZ) (Davies et al., 2018a). While none of these CE challenges are surprising, and they are well documented in the international literature, this paper focuses on understanding why these issues still exist, why there is not more impetus to address them, and how we might prompt more effective action on CE management in the future.

Building on (Davies et al., 2018a), we conducted a comparative study of CE policies and practices in Aotearoa NZ and in the Great Barrier Reef Marine Park (GBRMP), Australia, to elucidate how challenges to cumulative effects management might be overcome and to identify leverage points that are likely to apply across international contexts. These two studies operate on similar geographic and spatial scales and both have undergone and are undergoing processes of co-management of coastal and marine areas between government and Traditional Owners (in Australia) and Iwi (Indigenous tribes in Aotearoa NZ). However, a number of significant differences between the two cases, including the level, nature and role of government, governance practices, management approaches, public and commercial access, and resource use and allocation make for instructive comparisons. The case studies also facilitate comparison of how a comprehensive CE policy could be implemented both in the presence of a well-publicised and acknowledged environmental disaster, and in the absence of a clear driver (where CE management is potentially a low political and/or social priority).

The Aotearoa NZ case study involved a co-developed research project entitled "Navigating the implementation impasse: enabling interagency collaboration on cumulative effects," funded as part of the Sustainable Seas National Science Challenge ${ }^{1}$. In this case, research partners from Aotearoa NZ universities, research institutes, Māori consultancies and charitable trusts, government agencies, ministries, and private enterprises were mobilised to look more closely at how to undertake CE management in Aotearoa NZ. The Australian case study (GBRMP) illustrates a primarily reactive rather than proactive $\mathrm{CE}$ approach, where significant efforts have been made in recent years to address CE as a result of several crises that have focussed more attention on the degradation of the reef (e.g., McCook, 1999; De'ath et al., 2012; Ainsworth et al., 2016), as well as the economic and cultural effects of degradation (De Valck and Rolfe, 2018; Marshall et al., 2019).

Our comparative analysis seeks to identify some impetus for changing behaviours and management in the marine environment, particularly in cases where political will is lacking [political will is defined broadly here as "the extent of committed support among key decision makers for a particular policy solution to a particular problem" (Post et al., 2010)], or no significant environmental disaster has occurred to force the acknowledgement of ecosystem degradation. From this work, inferences can be drawn regarding (1) how to mobilise resources and political will to address CE, (2) how to deal with data scarcity and uncertainty, and (3) how to promote comprehensive and inclusive CE management of coastal and marine areas.

\section{BACKGROUND}

Ecosystem-based management (EBM) of coastal and marine areas aims to enhance the resilience, health and productivity of an interconnected social-ecological system (SES) through integration of policy and management of multiple uses and users (McLeod et al., 2005; Cormier et al., 2017; Gelcich et al., 2018). Consideration of governance practices is a primary consideration when looking to implement EBM, allowing for separation of the "governing system" from the "system being governed" (Fanning et al., 2007). However, while EBM principles are regularly referred to in national and international policy documents (Hewitt et al., 2018), references to EBM principles do not necessarily lead to their implementation in national policies (Gelcich et al., 2018; Sander, 2018).

Within the principles of EBM (Arkema et al., 2006; Gelcich et al., 2018), this paper focusses on the governance and

\footnotetext{
${ }^{1}$ https://sustainableseaschallenge.co.nz/programmes/our-seas/navigatingimplementation-impasse
} 
management of CE in coastal and marine areas, with a particular interest in understanding how to transform current arrangements so that they enhance the resilience, health and productivity of the SES. To transform the current system of CE management and governance, a novel suite of configurations must be introduced; this new system would necessarily consist of new components and ways of governing $\mathrm{CE}$, and thus have the potential to change system state variables, scales of key cycles, and the structures and processes that provide feedback (Olsson et al., 2006). Transformational change is likely to involve changes in perceptions, meanings and configurations of networks including leadership, power relations and institutional arrangements and structures (Folke et al., 2010).

Potential and actual CE can vary both spatially and temporally. In Aotearoa NZ, CE include a wide range of impacts on the coastal and offshore marine environment (MacDiarmid et al., 2012). In both coastal and offshore marine ecosystems, commercial, recreational and customary fishing directly impact on species and food webs through resource extraction, and for some fishing methods, result in significant disturbance to biogenic habitats on the seafloor. Other resource industries (oil and gas, mineral extraction, sand mining) and aquaculture as well as non-extractive industries (e.g., tourism, transport) may also impact on marine ecosystems. Climate change (temperature, sea level rise, increasing storm and wave events, ocean acidification) also has large impacts. Coastal marine systems are also impacted by sediments, nutrients and other pollutants derived from landbased activities. In the GBRMP, CE operate on local and global scales (Ortiz et al., 2018), including nitrogen inputs (Fraser et al., 2017), crown-of-thorns starfish outbreaks (Fraser et al., 2017; Vercelloni et al., 2017; Ortiz et al., 2018), climate change and extreme weather events such as cyclones (Fuentes et al., 2011; Ortiz et al., 2018), and degraded water quality and warming leading to coral bleaching (Ortiz et al., 2018).

\section{Statutory Context}

In Aotearoa NZ, coastal and marine management is covered by 25 statutes across 14 agencies and seven spatial jurisdictions (Bremer and Glavovic, 2013; Brake and Peart, 2015). Under the Resource Management Act 1991 (RMA) (Ministry for the Environment [MfE], 1991), responsibility for the sustainable and integrated management of marine natural resources (with the exception of fisheries) in the territorial sea (low water to 12 nautical miles) is devolved to regional and district councils (Severinsen and Peart, 2018). Sustainable management of natural resources (again with the exception of fisheries) within the Exclusive Economic Zone and on the continental shelf (from 12 to 200 nautical miles) is regulated by the Exclusive Economic Zone and Continental Shelf (Environmental Effects) Act (EEZ Act) 2012 (Ministry for the Environment [MfE], 2012). Other activities not covered by these two acts include maritime transport, submarine cables, and marine reserves; these activities are addressed under a variety of other Acts. While the need to avoid, remedy or mitigate cumulative effects is legislated within many of these Acts (e.g., the RMA, EEZ Act, and Fisheries Act), coordinated and consistent definitions and response to $\mathrm{CE}$ is lacking in Aotearoa NZ. Central government support for implementation, coordination, and collaboration across all levels of government is required to address CE in the marine environment (Bess, 2010), however, the fragmented approach to CE management in Aotearoa NZ makes consideration of multi-scale interactions challenging. This fragmentation is found globally; the scale at which management occurs often is not in alignment with the scale at which a problem occurs (Cumming et al., 2006; Guerrero et al., 2013). Short-sighted decision making is enhanced by the relatively short timeframe of political cycles, which hinder the formation and implementation of long-term management plans (Guerrero et al., 2013; Weeks et al., 2015).

In Australia, the GBRMP was established under the Great Barrier Reef Marine Park Act 1975; an intergovernmental agreement, the Offshore Constitutional Settlement, was put in place in 1979 to help protect the GBRMP (Hassan and Alam, 2019). The GBRMP was designated as a United Nations Educational, Scientific and Cultural Organization (UNESCO) World Heritage site in 1981. Due to continuing declines in reef health, UNESCO raised concerns over the state of the reef in 2012. This instigated the preparation of the Reef 2050 LongTerm Sustainability Plan (Reef 2050 Plan), which involved three levels of government working together to develop joint policies to control all activities that impact the marine park, including activities located outside the boundaries of the GBRMP. Strategic assessments, an integrated monitoring framework, and a review of protection mechanisms were associated with the development of the Reef 2050 Plan; these were carried out in partnership with traditional owners (TOs) and industry between 2012 and 2015 (Commonwealth of Australia, 2018). The following 2 years (2016/2017) saw devastating coral bleaching events occur within the GBRMP. In response to the bleaching events and the impact of Tropical Cyclone Debbie in 2017, an updated Reef 2050 Plan was expedited and released by the Australian and Queensland governments in July 2018 and is the overarching framework for protecting and managing the Reef until 2050 (Great Barrier Reef Marine Park Authority, and Queensland Government, 2018). The Australian Government, the Great Barrier Reef Marine Park Authority (GBRMPA) and the Queensland Government will lead implementation of the Reef 2050 Plan to protect the Outstanding Universal Value of the Reef. The Plan builds upon, and does not replace, the existing statutory and foundational management arrangements for the World Heritage site.

The Reef 2050 Plan responds to the pressures facing the Reef and aims to address cumulative impacts and increase the Reef's resilience to longer-term threats such as climate change. In recognition of the need to manage cumulative impacts (as outlined in the legally mandated Strategic Environmental Assessment undertaken jointly by GBRMPA and the Queensland Government), a review of current understanding with respect to cumulative impact management and application for management was undertaken in 2017. A suite of supporting policies and programms include the Reef 2050 Cumulative Impact Management Policy and Net Benefit Policy passed in July 2018 (Australian Government, 2018); these two documents, along with the Good Practice Management for the Great Barrier Reef document, are guidance materials to support implementation of the Reef 2050 Plan. In addition, the Reef 2050 Integrated 
Monitoring and Reporting Programm is a key part of the Reef 2050 Plan and will track the progress of the Reef 2050 Plan's outcomes and targets.

\section{Co-governance and Co-management Arrangements}

The involvement of Indigenous peoples in the management of CE is a feature of resource management in both Aotearoa NZ and GBRMP. In Aotearoa NZ, the Treaty of Waitangi signed in 1840 shapes the nature of the relationship between Iwi (Indigenous Māori tribes) and the Crown, whereby the Crown has obligations to recognise and provide for the rights of Māori under the Treaty. According to the Treaty and contemporary resource management regulations, tangata whenua (local Indigenous people) have the right to exercise kaitiakitanga (Māori stewardship according to their own aspirations and practices). Māori, therefore, have the right to be included in planning and decision making for natural resources through co-management and co-governance arrangements (Harmsworth et al., 2016; Lundquist et al., 2016; Webster and Cheyne, 2017), though statutory requirements vary substantially from consultation to co-governance across different legislative Acts and institutional practices (Joseph et al., 2018). Māori rights under the Treaty extend to the right to redress for Crown breaches of the Treaty (Harmsworth et al., 2016). Treaty claim settlements can include a formal apology, financial reparations for loss of land and resources, the right to first purchase of government infrastructure (such as airports and public land), and recognition of the groups' cultural association with specific lands and waters. Evolving recognition of Treaty rights and obligations toward stronger co-governance arrangements present opportunities for both mātauranga Māori (Māori Indigenous knowledge systems) and scientific knowledge to contribute to the evolution and enhancement of sustainable management goals and practices (Jollands and Harmsworth, 2007; Henwood and Henwood, 2011). Mātauranga Māori offers a holistic world view that emphasises relationality, interconnectedness, and the cultural and metaphysical dimensions of place (Harmsworth and Awatere, 2013; Clapcott et al., 2018).

Indigenous rights in Australia have a different history of implementation. Since the mid 1970's, there have been many important events that have contributed to the current state of sea-country management in and around the Great Barrier Reef (see Figure 1 in Dale et al., 2016). The ground-breaking "Mabo" decision (1992) acknowledged the rights of Indigenous peoples as the original occupants of Australia in the court system; the Native Title Act (1993) and "The Croker Island" decision (2001) established Indigenous rights to traditionally owned seacountry (Nursey-Bray and Rist, 2009; Dale et al., 2016). In the late 1990's, when plans were proposed to stop declining dugong populations which impacted on Traditional Owners abilities to harvest dugong from their sea-country, Traditional Use Marine Resource Agreements (TUMRAs) arose as a possible resolution to the tension around dugong and sea turtle harvesting (Dale et al., 2016). The establishment of the first TUMRA with the Girringun Community in 2005 enacted a co-management regime for the first time on the Great Barrier Reef (Nursey-Bray and Rist, 2009; Dale et al., 2016).

TUMRAs and Marine Park Indigenous Land Use Agreements (ILUAs) continue to be enacted to provide space for consideration of Indigenous perspectives and practices in the management, monitoring and compliance programms. TUMRAs in the GBRMP operate for a set timeframe after agreement between traditional owner groups, the GBRMPA (the lead authority responsible for the management of GBRMP) and the Department of National Parks, Recreation, Sport and Racing. In practice, these agreements tend to be descriptive documents outlining the role of traditional owner groups in management rather than facilitating co-management of Indigenous groups' traditional land and sea country.

\section{MATERIALS AND METHODS}

We conducted a comparative study of CE policies and practices in GBRMP and Aotearoa NZ using qualitative methods to collect and analyse data. Workshops and focus groups were employed to explore CE assessment and management frameworks, especially policies and practices, and the Trans-Tasman similarities and differences in addressing this global challenge. A review of international literature, focussed on understanding existing CE assessment and management frameworks, informed the design of workshops, focus groups and subsequent data analysis. Specifically, a range of policy documents were analysed using qualitative content analysis (e.g., Irvine et al., 2013; Takala et al., 2019; Table 1) to understand the governance and legislative arrangements regulating activities and the management of $\mathrm{CE}$ in Aotearoa NZ and the GBRMP, and to provide further context for the analysis (Charmaz, 2014).

The workshops and focus groups that formed the fieldwork portion of this research were designed to provide spaces for collaboration, co-learning and co-production of knowledge among scientists, practitioners, Māori and stakeholders with expertise and interests in CE in the marine environment (Le Heron et al., 2016). Study participants therefore comprised a purposive sample who could provide meaningful reflections on the topic of Trans-Tasman CE management. Utilising this approach meant that while meaningful and robust findings could emerge in relation to the study context, care had to be taken when making broad generalisations as a result of the research (Yin, 2011). Details of the workshop and focus group procedures are summarised in Table 2. All research procedures were approved by the NIWA Human Research Ethics Process prior to fieldwork and were performed in compliance with relevant human research ethics laws and institutional guidelines. All workshops and focus groups were led by experienced facilitators.

The primary Aotearoa NZ case study workshop was conducted in Wellington, New Zealand, and included 14 representatives from diverse backgrounds in local government, central government, industry, research organisations, Māori organisations, and Māori interests. This workshop focussed on understanding how $\mathrm{CE}$ are currently managed in light of legislative requirements and mechanisms, as well as identifying 


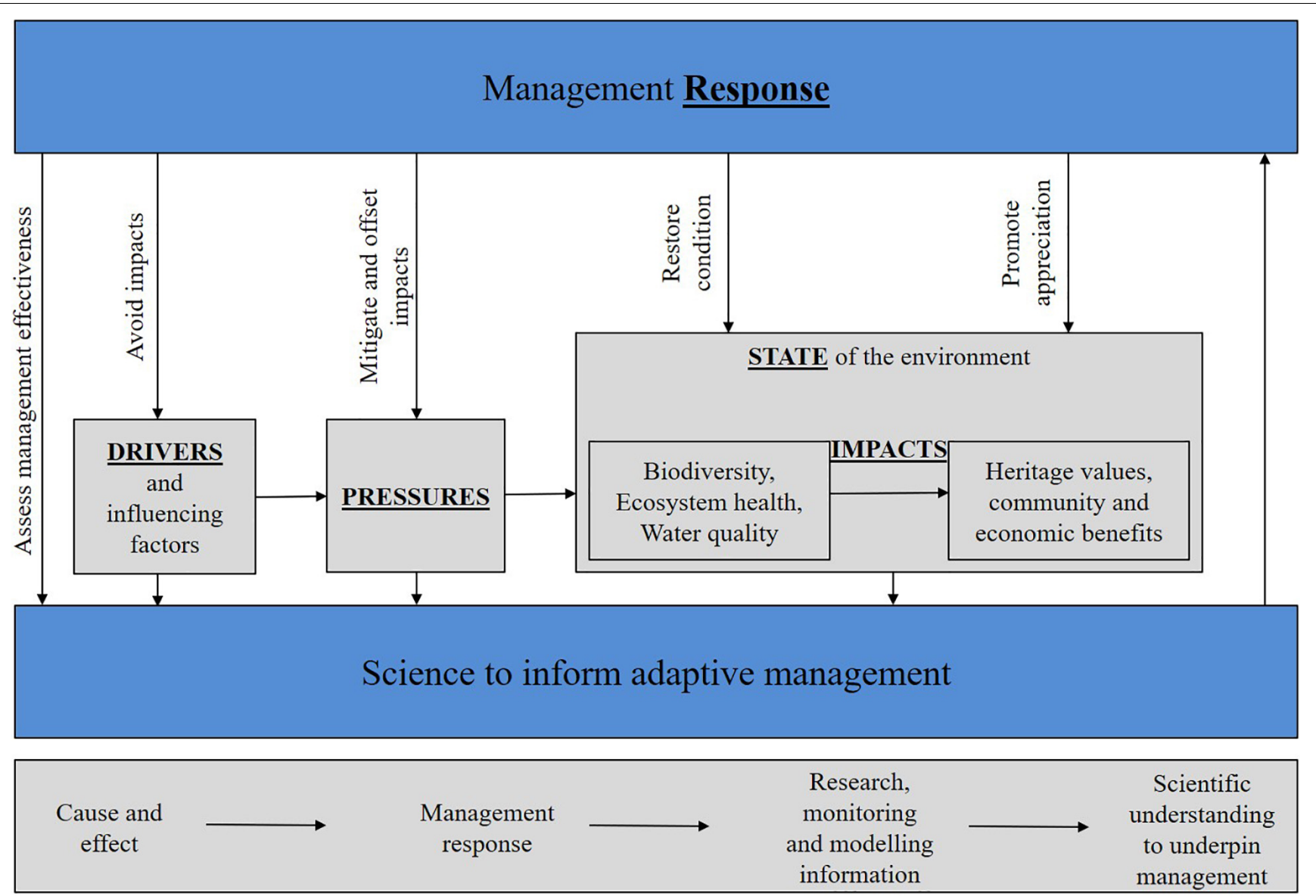

FIGURE 1 | Reef 2050 Plan adaptive management framework (Adapted from Commonwealth of Australia, 2018: 77).

TABLE 1 | Policy documents analysed to understand the governance and legislative arrangements regulating activities and the management of cumulative effects in Aotearoa NZ and the GBRMP.

\begin{tabular}{|c|c|c|c|c|}
\hline Institution & Year & Title & Country & References \\
\hline Bay of Plenty Regional Council & 2011 & Regional Coastal Environment Plan & New Zealand & Bay of Plenty Regional Council, 2011 \\
\hline Auckland Council & 2018 & Auckland Unitary Plan, Chapter F Coastal & New Zealand & Auckland Council, 2016 \\
\hline Marlborough District Council & 2011 & $\begin{array}{l}\text { Marlborough Sounds Resource } \\
\text { Management Plan }\end{array}$ & New Zealand & Marlborough District Council, 2011 \\
\hline Environment Southland & 2013 & Coastal Plan & New Zealand & Environment Southland, 2013 \\
\hline Ministry for the Environment & 2010 & NZ Coastal Policy Statement & New Zealand & Department of Conservation, 2010 \\
\hline Department of Conservation & 2017 & $\begin{array}{l}\text { Review of the effect of the NZCPS } 2010 \text { on } \\
\text { RMA decision making }\end{array}$ & New Zealand & Department of Conservation, 2017 \\
\hline Environmental Defence Society & 2018 & $\begin{array}{l}\text { Reform of the Resource Management } \\
\text { System. The Next Generation. Synthesis } \\
\text { Report. }\end{array}$ & New Zealand & Severinsen and Peart, 2018 \\
\hline Great Barrier Reef Marine Park Authority & 2017 & GBR Reef Blueprint & Australia & Great Barrier Reef Marine Park Authority, 2017 \\
\hline $\begin{array}{l}\text { Queensland Government/Commonwealth } \\
\text { of Australia }\end{array}$ & 2014 & $\begin{array}{l}\text { Great Barrier Reef Region Strategic } \\
\text { Assessment Programm Report } 2014\end{array}$ & Australia & Great Barrier Reef Marine Park Authority, 2014b \\
\hline Great Barrier Reef Marine Park Authority & 2014 & Great Barrier Reef Outlook Report 2014 & Australia & Great Barrier Reef Marine Park Authority, 2014a \\
\hline Commonwealth of Australia & 2018 & Reef 2050 Long-Term Sustainability Plan & Australia & Commonwealth of Australia, 2018 \\
\hline Great Barrier Reef Marine Park Authority & 2018 & $\begin{array}{l}\text { Good Practice Management for the Great } \\
\text { Barrier Reef }\end{array}$ & Australia & Great Barrier Reef Marine Park Authority, 2018b \\
\hline Great Barrier Reef Marine Park Authority & 2018 & Net Benefit Policy & Australia & Great Barrier Reef Marine Park Authority, 2018c \\
\hline Great Barrier Reef Marine Park Authority & 2018 & Cumulative Impact Management Policy & Australia & Great Barrier Reef Marine Park Authority, 2018a \\
\hline
\end{tabular}


TABLE 2 | Summary of workshop and focus group details.

\begin{tabular}{|c|c|c|c|c|}
\hline & Wellington (Aotearoa NZ) & Brisbane (GBRMPA) & Hobart (Aotearoa NZ) & Hobart (Aus/GBR) \\
\hline Date & 7 August 2017 & 6 September 2018 & 3 September 2018 & 3 September 2018 \\
\hline $\begin{array}{l}\text { Number of } \\
\text { participants }\end{array}$ & 14 & 5 & 3 & 7 \\
\hline Range of expertise & $\begin{array}{l}\text { Representatives from local } \\
\text { government, central government, } \\
\text { industry, research organisations, } \\
\text { Māori organisations, and Māori } \\
\text { interests }\end{array}$ & $\begin{array}{l}\text { Representatives from different } \\
\text { disciplinary backgrounds working } \\
\text { in the same organisation }\end{array}$ & $\begin{array}{l}\text { Representatives from different } \\
\text { disciplinary backgrounds and } \\
\text { Aotearoa NZ organisations (e.g., } \\
\text { from research and government) }\end{array}$ & $\begin{array}{l}\text { Representatives from different } \\
\text { disciplinary backgrounds and } \\
\text { expertise from two Australian } \\
\text { research organisations }\end{array}$ \\
\hline Sampling methods & $\begin{array}{l}\text { Purposive (comparability) } \\
\text { sampling (Teddlie and Yu, 2007) }\end{array}$ & $\begin{array}{l}\text { Snowball technique (Fontana and } \\
\text { Frey, 1998) }\end{array}$ & $\begin{array}{l}\text { Purposive (comparability) } \\
\text { sampling (Teddlie and Yu, 2007) }\end{array}$ & $\begin{array}{l}\text { Purposive (comparability) } \\
\text { sampling (Teddlie and Yu, 2007); } \\
\text { Snowball technique (Fontana and } \\
\text { Frey, 1998) }\end{array}$ \\
\hline Typology & $\begin{array}{l}\text { Single focus group (Nyumba } \\
\text { et al., 2018) }\end{array}$ & $\begin{array}{l}\text { Single focus group (Nyumba } \\
\text { et al., 2018) }\end{array}$ & $\begin{array}{l}\text { Respondent moderator focus } \\
\text { group/workshop (Nyumba et al., } \\
\text { 2018) }\end{array}$ & $\begin{array}{l}\text { Respondent moderator focus } \\
\text { group/workshop (Nyumba et al., } \\
\text { 2018) }\end{array}$ \\
\hline $\begin{array}{l}\text { Focus of } \\
\text { discussions }\end{array}$ & $\begin{array}{l}\text { Understanding how CE are } \\
\text { currently managed in light of } \\
\text { legislative requirements and } \\
\text { mechanisms, as well as } \\
\text { identifying management practices } \\
\text { that fall outside of formal } \\
\text { requirements; key drivers, } \\
\text { pressures, values, and possible } \\
\text { responses to CE that might align } \\
\text { across scales, including } \\
\text { identification of factors that can } \\
\text { help or hinder resource } \\
\text { management of CE. }\end{array}$ & $\begin{array}{l}\text { Governance and management of } \\
\text { the GBRMP and implementation } \\
\text { of the Reef Plan, including the } \\
\text { various actions and management } \\
\text { plans preceding the Reef Plan. } \\
\text { This included a discussion of the } \\
\text { inter-governmental and regulatory } \\
\text { arrangements (Federal } \\
\text { government and Queensland } \\
\text { State Government) to manage } \\
\text { impacts of activities in the GBR } \\
\text { and catchment area. }\end{array}$ & \multicolumn{2}{|c|}{$\begin{array}{l}\text { Understanding scientific approaches to assessing CE (including } \\
\text { modelling, risk assessments, strategic assessments and indicators), as } \\
\text { well as legislative and governance arrangements to specifically manage } \\
\text { CE in the GBRMP. Identification of helping and hindering factors in } \\
\text { GBRMP and Aotearoa NZ to begin to elucidate commonalities and } \\
\text { differences across the two case study locations. }\end{array}$} \\
\hline
\end{tabular}

management practices that fall outside of formal requirements; for example, the practice and exercise of kaitiakitanga among Māori, and non-statutory co-governance and co-management arrangements. This workshop also sought to investigate some of the key drivers, pressures, values, and possible responses to $\mathrm{CE}$ that might align across scales, including identification of factors that can help or hinder resource managers in managing CE.

The Australian case study was comprised of two components; the first was a Trans-Tasman collaborative workshop held in Hobart, Australia which involved 10 representatives with different disciplinary backgrounds and expertise (seven from the Australian context and three from the Aotearoa NZ context). This workshop explored a broad CE research agenda, focussing on understanding scientific approaches to assessing CE, as well as legislative and governance arrangements to specifically manage CE in the GBRMP. One of the breakout sessions focussed on identifying and comparing helping and hindering factors in GBRMP and Aotearoa NZ to begin to elucidate commonalities and differences across the two case study locations.

The second Australian component was a focus group conducted in Brisbane, Australia, with five representatives from GBRMPA. Due to the interests and expertise of the participants, the Brisbane focus group concentrated primarily on questions regarding $\mathrm{CE}$ management and governance implementation. The discussion centred on the governance and management of the GBRMP and implementation of the Reef Plan, including the various actions and management plans preceding the Reef Plan. This included a discussion of the inter-governmental and regulatory arrangements (Federal Government and Queensland State Government) to manage impacts of activities in the GBR and catchment area.

Summary notes from each workshop/focus group were taken by the researchers and/or a research assistant, compiled into a single document and provided to participants for clarification and amendment. This document was then analysed using constructivist grounded theory (Charmaz, 2014) to guide the comparative analysis of CE approaches across the two cases. The data were coded using QSR International NVivo 12 software and memoing was used to record the process of emergence and relationships between themes (Strauss and Corbin, 1990). Four central themes associated with CE management policies and practices emerged from the data analysis and are considered throughout this paper (see Tables 3, 4 for details):

(1) Legislative framing;

(2) Data, systematic assessments, and uncertainty;

(3) Values, rights and decision making;

(4) Linking across scales.

Each theme links to at least one of the three key $\mathrm{CE}$ management challenges described in the introduction. Our initial analysis of these themes highlighted factors that hinder and/or help progress effective CE management across diverse cycles, stages, timeframes, actors, scales, and cultures of governance and decision making (after Jann and Wegrich, 2007). We then conducted a further analysis to consider whether and how CE 


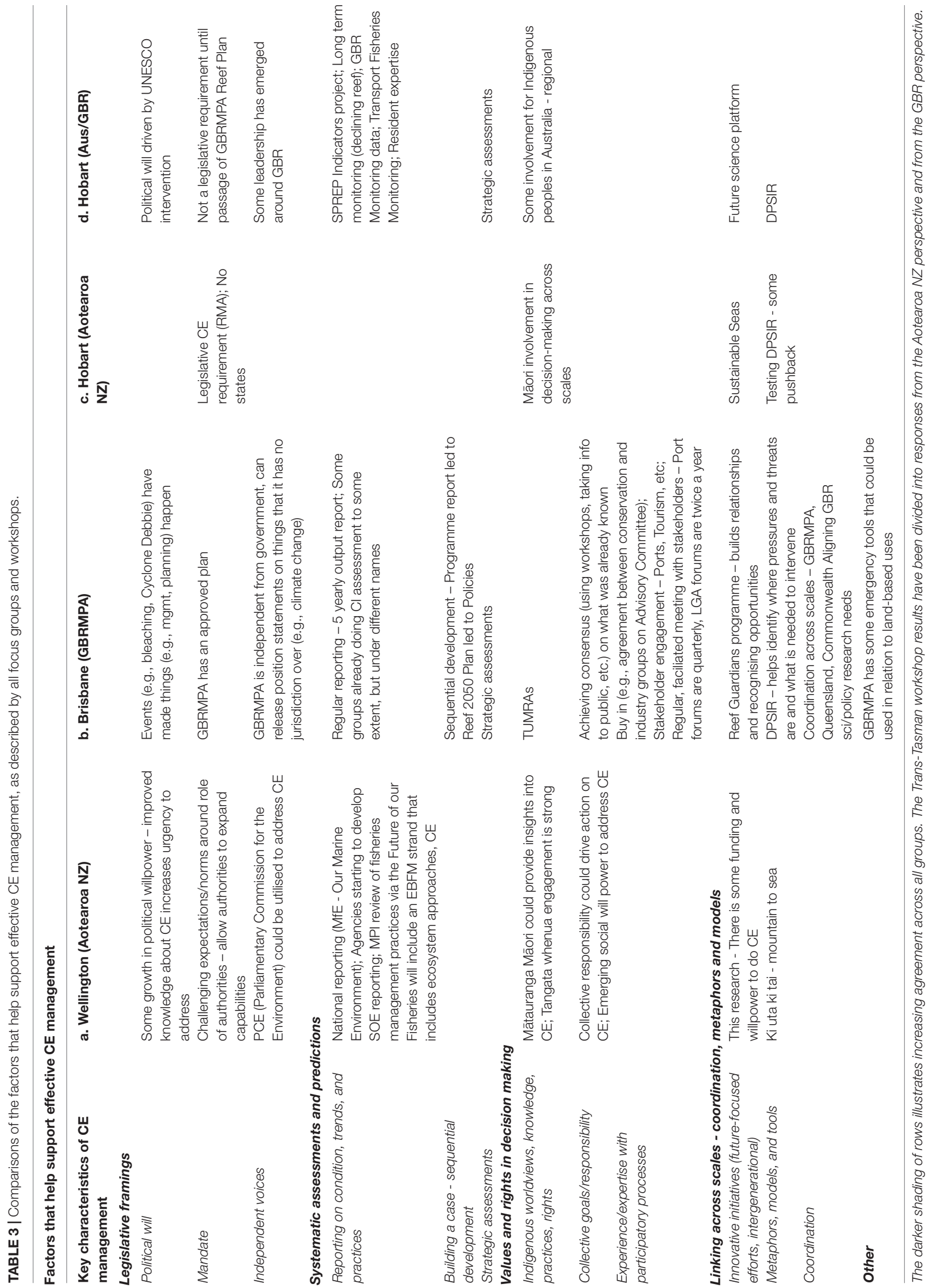




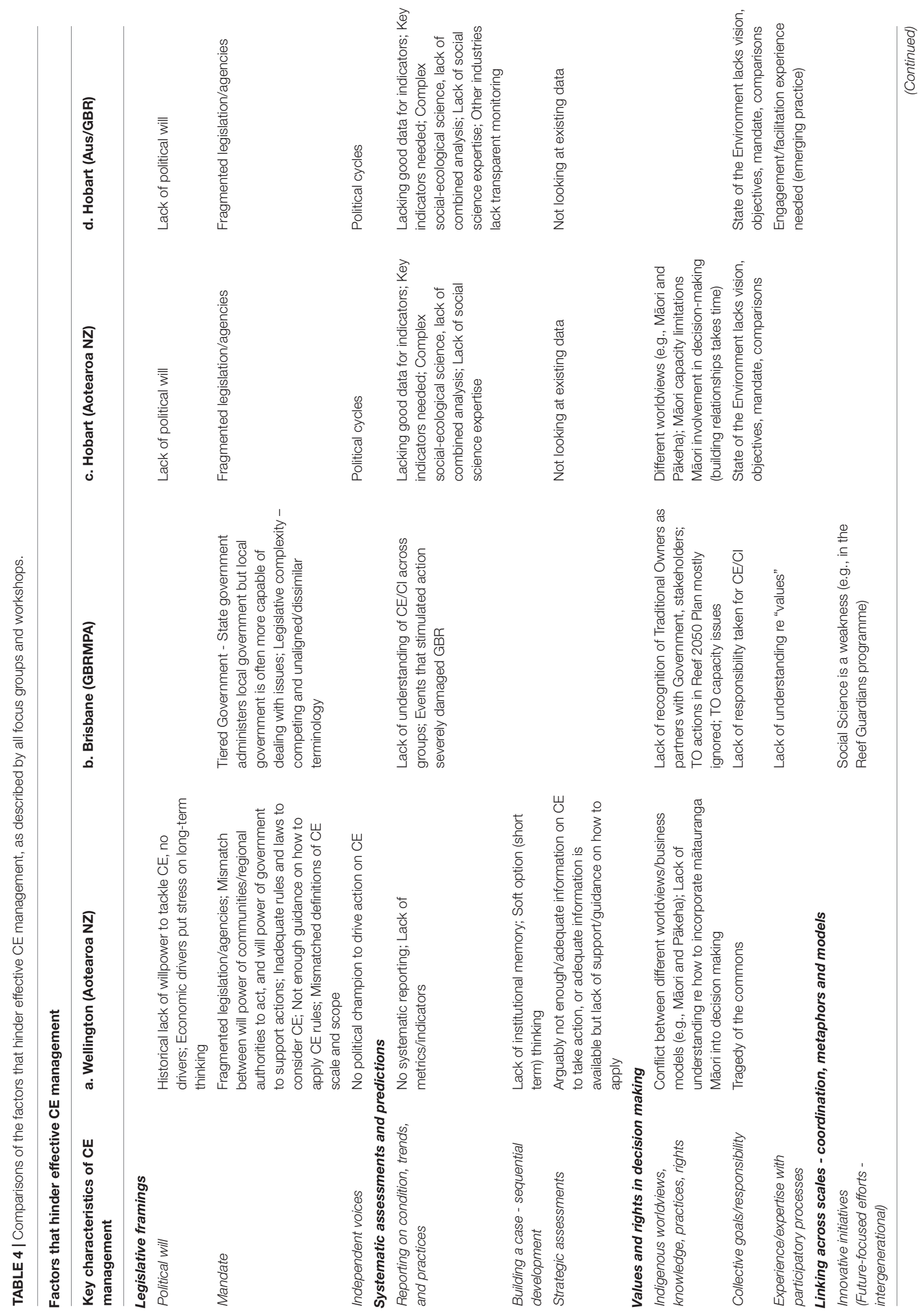


management and/or governance transformations have occurred and in what ways these transformations have addressed the three key CE management challenges. The phases and characteristics of transformational change that we evaluate our data against are outlined in Table 5.

\section{RESULTS}

\section{Legislative Framings}

Participants at the focus group and workshops for both case studies identified legislative and sectoral fragmentation as a key challenge for CE management, but also identified a number of other aspects of legislative framing that influenced their ability to effectively manage for CE (either positively or negatively). Participants spent time discussing the need for political will to address CE (Tables 3, 4), describing it as a crucial element of CE management implementation. Although the term "political will" is a notoriously slippery concept to define, we are confident that participants were using the term in alignment with the definition provided by Post et al. (2010). In the GBRMP context, the importance of having an external driver (UNESCO) and major environmental events such as coral bleaching were repeatedly emphasised in relation to generating the political will to address CE. In the Aotearoa NZ context, the lack of political will was perceived to be a major constraint to making progress on $\mathrm{CE}$ management; this was linked to the absence of external drivers that might influence $\mathrm{CE}$ management, and the influence of short-term economic drivers. However, a growing awareness of the problems associated with $\mathrm{CE}$ was seen as a helping factor that could encourage the development of more political will to address CE.

Having the legal mandate to address CE was another key factor that participants raised at all of the workshops/focus groups (Tables 3, 4). Although there is a legal mandate in Aotearoa $\mathrm{NZ}$ for CE management under the RMA, guidance on how this should be undertaken was missing, and it has therefore remained a low priority. Participants suggested this was due to the previously mentioned lack of political will. Some participants also pointed out that mismatches between having a legal imperative to progress CE management, having a moral inclination to do so, and having the support of the government to take action on CE were difficult to navigate. However, participants pointed out that the fact that some sense of obligation did exist was probably a positive sign. In the GBRMP, a legislative requirement designed to specifically address CE was not in place until the Reef 2050 Plan was passed in 2018. Again, the passing of this plan was largely attributed to the increased political will that emerged in recent years as a result of several external drivers. Participants from Aotearoa NZ and Australia rued the fragmented management and governance regimes that have made it difficult to coordinate a $\mathrm{CE}$ mandate that stretches across scales. They also recognised that practitioner expertise was often local/regional, while the guidance came from a higher scale (state/national). This disconnect has been difficult to overcome except through the establishment of hard-earned, long suffering collaborative efforts (as in the efforts to establish the Reef 2050 Plan). 
TABLE 5 | Evaluation criteria associated with transformational change in CE management and governance systems.

\begin{tabular}{|c|c|}
\hline $\begin{array}{l}\text { Phases and } \\
\text { characteristics of } \\
\text { transformational change }\end{array}$ & Description \\
\hline Preparing for change & (Olsson et al., 2006) \\
\hline $\begin{array}{l}\text { Building knowledge and } \\
\text { networking }\end{array}$ & $\begin{array}{l}\text { Networks that include actors operating at a range } \\
\text { of scales, build trust, encourage information sharing } \\
\text { and the creation of new knowledge, can help to } \\
\text { manage conflicts. }\end{array}$ \\
\hline Leadership & $\begin{array}{l}\text { Key individual and/or organisational leaders prepare } \\
\text { the system for change, especially regarding the } \\
\text { development of strategies for exploring new system } \\
\text { configurations. Motivate, align, and inspire others to } \\
\text { invest in alternative approaches. }\end{array}$ \\
\hline Windows of opportunity & (Kingdon, 1995) \\
\hline Problem awareness & $\begin{array}{l}\text { A problem is broadly recognised by a collective of } \\
\text { disparate actors }\end{array}$ \\
\hline Solutions available & $\begin{array}{l}\text { An acceptable solution or suite of solutions is } \\
\text { available and supported by key actors }\end{array}$ \\
\hline Political action & $\begin{array}{l}\text { The political climate is open to change and } \\
\text { constraints do not prohibit actions. }\end{array}$ \\
\hline Navigating the transition & (Olsson et al., 2006; Folke et al., 2010) \\
\hline $\begin{array}{l}\text { Emergence of shadow } \\
\text { networks }\end{array}$ & $\begin{array}{l}\text { Often informal networks that are willing to } \\
\text { experiment and generate alternative solutions to } \\
\text { emerging problems, seek tools and data to } \\
\text { navigate transitions and institutionalise new } \\
\text { approaches, emphasise political independence. }\end{array}$ \\
\hline Emergence of leadership & $\begin{array}{l}\text { Visionary leadership that emerges at a key moment } \\
\text { (often a crisis) and can reconceptualise issues; } \\
\text { generate and integrate a diversity of ideas, } \\
\text { viewpoints, and solutions; communicate and } \\
\text { engage with key individuals in different sectors; } \\
\text { span scales; promote and steward } \\
\text { experimentation; recognize or create windows of } \\
\text { opportunity; and promote novelty by combining } \\
\text { different networks, experiences, and expertise. }\end{array}$ \\
\hline
\end{tabular}

The role of independent voices and leadership was also discussed by many participants, especially in the Australian contexts (Tables 3, 4). GBRMPA is an independent organisation, which means that while it must operate within the constraints of its mandated authority, it can raise issues of importance without facing political repercussions (e.g., release position statements on issues that are technically outside its jurisdiction such as climate change). Participants described this independence as crucial to getting the best possible CE management plan in place. From the Aotearoa NZ perspective, there has been little discussion about CE management until recently and therefore no political champion has yet emerged to drive action on CE management. Approaches to $\mathrm{CE}$ assessment and management have thus far largely relied on case law $^{2}$ related to resource decisions made through the courts (Milne, 2008) and regional efforts by councils or community groups.

\footnotetext{
${ }^{2}$ Notable cases that have influenced decision-making in relation to CE in Aotearoa NZ include: Dye v Auckland Regional Council (2002), RJ Davidson Family Trust v Marlborough District Council $(2016,2017)$ and Okura Holdings Limited v Auckland City Council (2018).
}

\section{Data, Systematic Assessments, and Uncertainty}

The kinds of reporting needed to develop CE management plans, guidelines, and assessments were discussed at length in all workshops and focus groups (Tables 3, 4). The GBR context is much further along this path than Aotearoa NZ. The Australian Institute of Marine Science (AIMS) Long-Term Monitoring Program (LTMP) for the GBR has been going since 1993 and a long-term monitoring programm that focusses on social and economic data for the GBR was instigated in 2013 (Marshall et al., 2013). This concerted effort in data collection has enabled the GBR to make relatively speedy progress on developing assessments, risk management plans, and other related CE guidelines. The GBRMPA is required to produce a summary report that collates this monitoring data at least every 5 years.

While the New Zealand Ministry for the Environment (MfE) has started to produce national-scale marine reports every 3 years (Ministry for the Environment [MfE], 2015), there is little cohesive long-term data or other standardised monitoring data for these reports to collate, making these efforts an important but limited step for Aotearoa NZ. The 2016 MfE report, Our Marine Environment 2016, begins with a discussion of the uncertainty facing coastal and marine systems in Aotearoa NZ due to a lack of data:

"We cannot quantify the state of marine habitats at a national level, or the full ecological impacts of commercial, recreational or customary fishing on coastal and open ocean ecosystems" (Ministry for the Environment \& Statistics NZ, 2016: 8).

The lack of credible metrics/indicators associated with CE has constrained efforts in both countries (Tables 3, 4). The Secretariat of the Pacific Regional Environment Programme (SPREP) has instigated a large-scale project to create core indicators, which has started to address this gap in the GBR. Meanwhile, a range of projects are in development in Aotearoa NZ to investigate the suitability of different indicators for environmental health that could be used to inform CE management and assessment (e.g., Department of Conservation, 2000). However, participants from both Aotearoa NZ and GBR contexts admitted there was likely more data available than anyone realised, and an essential part of the work will be to take adequate time to collate and analyse this data.

In addition to reporting on coastal and marine status and trends, a series of strategic assessments undertaken in the GBR context have provided crucial information that has driven the CE management process forward (Anthony et al., 2013). The Cumulative Impact and Structured Decision-Making (CISDM) framework was designed to understand the cumulative impacts of multiple stressors and incorporate this knowledge into management decisions. The GBRMPA focus group pointed out that having a long term, sequential series of efforts addressing $\mathrm{CE}$ helped build a case for and socialise the implementation of the Reef 2050 Plan.

The cumulative impacts policy provides for a strategic, systematic and consistent approach for managing and reducing cumulative impacts on the GBRMP (Stelzenmüller et al., 2018; 
Figure 1). The policy outlines a Drivers-Pressures-State-ImpactResponse (DPSIR) framework for assessing condition and trend, along with values and attributes of the GBR. It also provides guidance on how to deliver net benefit outcomes for the reef using a range of approaches including working collaboratively with stakeholders at local, regional, national and international scales.

\section{Values and Rights in Decision Making}

Participants acknowledged that under current circumstances it is difficult to determine responsibility for $\mathrm{CE}$, and that this is a significant challenge for CE management (Tables 3, 4). Mechanisms to promote either an individual or collective sense of responsibility are actively being sought in both the Aotearoa NZ and GBR contexts. The GBRMPA focus group described several mechanisms (e.g., workshops, public forums) that have been utilised in an attempt to gain consensus and move management decision making forward. In the Aotearoa NZ context, participants referred to the "tragedy of the commons" (Hardin, 1968) to summarise many of the challenges faced by proposals that relied on collective management of coastal and marine areas.

All participants agreed that the need to develop and socialise a clear and unifying vision and objectives is needed to guide any cohesive CE management process. Those in the Hobart workshop agreed that the current State of the Environment reports (e.g., Ministry for the Environment \& Statistics NZ, 2015) do not provide this clarity or vision. However, there are signs that $\mathrm{CE}$ policies are gaining interagency and multi-scalar support, although satisfactory implementation is still in progress. For example, the Reef 2050 Plan was recently passed into law, and the Plan's implementation is overseen through the Great Barrier Reef Ministerial Forum (which includes representation from both the Australian and Queensland governments) (Great Barrier Reef Marine Park Authority, and Queensland Government, 2018). At the core of the Reef 2050 Plan is an outcomes framework that may drive progress toward an overarching vision:

\footnotetext{
"To ensure the Great Barrier Reef continues to improve on its Outstanding Universal Value every decade between now and 2050 to be a natural wonder for each successive generation to come" (Commonwealth of Australia, 2018: 1).
}

Participants agreed that establishing cohesive CE management protocols requires a substantial investment in participatory processes. The Brisbane focus group and the Hobart workshop participants described the value in having expert and/or independent facilitators involved in running participatory processes (Tables 3, 4). The need to get buy-in and agreement from both conservation and industry groups was a significant hurdle for the Reef 2050 Plan and required extensive stakeholder engagement and conflict management. In the Aotearoa NZ context, participatory processes are perhaps more standardised than in Australia due to RMA consultation requirements that have been in place since 1991, but evidence suggests that there is considerable diversity in how long-term, large-scale engagement with diverse and often conflicting interests plays out (Davies et al., 2018b). Another crucial factor related to participation is the rights of Indigenous partners in CE management decision making. While in Aotearoa NZ, Treaty agreements provide some guidelines and protections regarding how co-management and co-governance practices should unfold, participants in the GBRMPA focus group described the need to recognise TOs as partners and provide support for participation and capacity building as a major gap in terms of including values and rights in CE management and decision making, even under the recently implemented Reef 2050 Plan.

Knowing the distribution of human values and impacts on marine environments, spatially and temporally, is key to successful CE management (Jones et al., 2018). The absence of large-scale social and cultural data sets in both Aotearoa NZ and Australia complicates attempts to incorporate Indigenous values into ecosystem-based management (Table 4). Much of the information available is in an unquantified or unquantifiable form and seen as unsuitable for inclusion in traditional western scientific monitoring and management programms. Some traditional use and value data are deemed not sharable for cultural reasons by Indigenous communities. As with the existing ecological data sets, the social and cultural information available is not conducive to facilitating assessment or management of large scale coastal and marine systems facing issues across multiple spatial and temporal scales, but perhaps could be viable as part of a more localised or regional CE management cluster.

\section{Linking Across Scales - The Role of Metaphors and Models}

The approach taken to $\mathrm{CE}$ assessment and decision making can differ depending on who is undertaking the assessment, the purpose for which it is intended and whether it is to be done at a strategic level or a project level. In Aotearoa NZ, operators in the marine environment are required to consider the $\mathrm{CE}$ of proposed activities. However, the method and scope of the assessment that is undertaken can change dramatically between applications, and decision makers must be able to evaluate and make a determination on these assessments. Decisions about the scope of the assessment (activity vs. receptor) and the spatial and temporal scale all influence CE assessments and their reliability (Natural England, 2014).

Both case studies emphasised emerging, future-focussed, innovative initiatives that bring some optimism to the CE management discussion (Table 3). In the Aotearoa NZ context, the Sustainable Seas National Science Challenge is providing funding for work on CE through to 2024. In GBR, the Reef Guardians Schools Programm (Day and Dobbs, 2013) is an action-based sustainability education programm that builds relationships and recognises opportunities. Participants and teachers are said to change the way they do things and how they think about their effect on the reef (Evans, 2011). There was some admission, however, that work in the social sciences is a large gap in many of these efforts (Table 3).

Both case studies have developed metaphors, models, and tools to address the many complexities associated with CE management (Table 3). The DPSIR framework (Commonwealth of Australia, 2018) has been used extensively to deal with CE in GBRMP. Participants touted DPSIR as a tool that compromises 
some of the details preferred by scientists but makes sense to most stakeholders. The Aotearoa NZ Team is also using a modified DPSIR framework to progress discussions across groups because of its flexibility and transparency. The tool is not perfect; issues have been identified in terms of an over-emphasis on pressurestate interactions, with inadequate treatment or integration of management responses and impacts to human well-being (Lewison et al., 2016; Patrício et al., 2016), but it does help to identify where pressures and threats are in a system, and therefore possible options for intervention. In Aotearoa NZ, ki uta ki tai-from mountain to sea-is a Māori concept that emphasises the interconnectedness of ecosystems inclusive of people (Schiel and Howard-Williams, 2016; Tipa et al., 2016; Kainamu-Murchie et al., 2018). This concept aligns closely with the commitment to EBM required to effectively manage cumulative effects in complex marine systems. The ki uta ki tai strategy provides a way to conceptualise and manage linkages across scales and cultures. This is an important unifying metaphor that is somewhat missing from the GBR context.

\section{DISCUSSION}

This research has thus far provided important insights into the barriers and enablers associated with CE management and why they persist (or not) across a range of scales, legislative framings, and cultures. The discussion that follows will use this empirical data to tease out lessons about how to prompt more effective action on CE management in the future. We do this by considering how well the Aotearoa NZ and GBRMP case studies align with qualities associated with transformative management and governance (Table 5). Although our findings come from an Oceania context, by viewing this data through a transformative lens we illuminate the broader implications of this research for CE management in other contexts around the world.

\section{Preparing for Change}

Building knowledge and networking are key aspects of successful implementation of CE governance and management transformations. Not surprisingly, results from this study indicate that actors in the GBRMP case study have done more to prepare for a CE management transformation than the actors in the Aotearoa NZ case study. Study participants pointed out that the long-term monitoring programms in GBRMP have enabled relatively speedy progress on developing assessments, risk management plans, and other related CE guidelines. Mechanisms that promote participation and a sense of responsibility when it comes to CE governance and management have also been actively developed in GBRMP, with a substantial amount of work aimed at sharing information across scales and building trust among actors. There is no equivalent work in the Aotearoa NZ context beyond the co-developed project associated with this study.

The collective efforts associated with CE management in GBRMP have paid off, and the governance and management of the area has progressed through at least the early stages of a transformation (Folke et al., 2010). However, data that are available for $\mathrm{CE}$ assessments and management in both cases are still considered by study participants to be fragmented, not standardised and often combined with high levels of uncertainty, making system-based assessments and predictions difficult. Failure to adequately address uncertainty has directly led to many cases of failed management around the world (Ludwig et al., 1993; Ralls and Taylor, 2000).

While government agencies in Aotearoa NZ have recognised the existence of $\mathrm{CE}$ and the role that local coastal and marine systems play in the wider global ocean ecosystem, long-term ecological-scale data is needed in order to manage these systems effectively. There is a better record of collecting ecological data and conducting strategic analyses in GBRMP, but both case studies reveal substantial gaps in the social and cultural data needed to effectively link ecological data to behaviour changes and implementation that would be effective for CE management. Further, understanding of interactions between stressors are limited, and better understanding of whether component and system interactions are additive or synergistic (i.e., total effect is great than the sum of the parts) can assist in more efficient CE management (Burkepile and Hay, 2006; Crain et al., 2008; Harvey et al., 2013; Przeslawski et al., 2015).

Another key component of preparing for change is individual and/or organisational leadership that develops strategies for exploring new configurations for CE management (Olsson et al., 2006). GBRMPA has been touted for its willingness to reorganise internal structures and test innovative management strategies to gain more traction on GBRMP management challenges (Folke et al., 2010). In contrast, in Aotearoa NZ, there has been little cohesive leadership taken by any government authority on CE management beyond the recognition in recent State of the Environment reports that it is a substantial concern (Ministry for the Environment \& Statistics NZ, 2015, 2016).

\section{Windows of Opportunity}

Policy changes are affiliated with a "window of opportunity" by Kingdon (1995); he argues that transformations are most likely when problems, solutions, and politics all converge at a critical moment. Ecological crises and other periods of rapid change can similarly provide windows of opportunity that trigger the emergence of new networks and promote new forms of governance (Folke et al., 2005; Olsson et al., 2006). In this study, we are interested in understanding how to promote windows of opportunity even when there is no immediate crisis or other substantial external driver.

\section{Problem Awareness}

Problem awareness can become very challenging when the problems are as complex and cross-scale as something like climate change or $\mathrm{CE}$ management. People often struggle to connect their mainly land-based activities to outcomes in the oceans (McKinley and Fletcher, 2012). This contributes to the inability of traditional activity-led management to account for the interconnected nature of terrestrial, atmospheric and coastal and marine systems, let alone the social, political, economic and cultural (SPEC) elements of these systems (Wu et al., 2015; Allison et al., 2018). In the GBRMP case study, the unifying 
entity of the reef has provided a focal point (albeit associated with multiple diverse meanings, identities and values) to guide the development of problem awareness and subsequent work on $\mathrm{CE}$ governance and management transformations.

In Aotearoa NZ, the biggest challenges to transforming CE governance and management could arguably arise in relation to developing a cohesive problem awareness, and thus linking knowledge, values, and actions across scales (Davies et al., 2018a). This process requires coordination of CE management among institutions and agencies, a notoriously difficult task (Lundquist et al., 2016). The RMA should supply some level of overarching coordination to legislative frameworks and the agencies responsible for CE management in Aotearoa NZ, but many instances of fragmentation remain, not the least of which are the distinctions between the territorial sea and the EEZ, and the exclusion of fisheries management from consideration (Severinsen and Peart, 2018). However, emerging efforts to conduct mission-led inter- and transdisciplinary science (such as the Sustainable Seas National Science Challenge) indicate that there is an increasing awareness in some sectors that $\mathrm{CE}$ governance and management transformations are needed. Similar integrated science and society approaches have also emerged elsewhere around the world to address complex, crossscale challenges (e.g., Collins et al., 2007). It has also been suggested that taking a local/regional level approach and then linking to principles-based approaches that apply at higher scales could be a more efficient way to address CE governance and management challenges (Crease et al., 2019).

\section{Solutions Available}

One of the key areas of development in Aotearoa NZ is the incorporation of Māori concepts that focus on place-based interconnections of ecosystems. Mātauranga Māori offers a place-based understanding of environmental change derived from intergenerational observations and the transmission of that knowledge; this kind of information is necessary for managing CE. Meanwhile, the principles and values associated with the ki uta ki tai (mountain to sea) concept can provide a unifying metaphor that aligns with healthy ecosystems and can leverage both scientific and customary knowledge to support implementation (Jackson et al., 2018).

Crown obligations to Māori under the Treaty of Waitangi and as incorporated into contemporary legislation (such as the RMA) also provide Māori with a strong negotiating position (relative to many other Indigenous nations) (Bryan, 2017; Jackson, 2018). This means Māori values and rights are often positioned at the forefront of natural resource management negotiations and decision making, rather than being assumed as part of a process in which a single culture dominates. The prominence of Māori knowledge, culture and tikanga (ethical or appropriate ways of doing) has been further strengthened in Aotearoa NZ decision making through the ongoing settlements of Treaty claims and establishment of co-governance and co-management agreements between relevant councils and Iwi around the country (Mutu, 2012; Ruru, 2018; Te Aho, 2018). Treaty settlements have also resulted in substantial resource (natural and financial) (re)allocation to Iwi. The increasingly powerful position of Māori/Iwi can provide unique opportunities to explore alternative approaches to CE management. For example, a ki uta ki tai (mountains to sea) approach to CE management that draws from traditional and contemporary Māori approaches to natural resource management (Kainamu-Murchie et al., 2018) provides a proactive, holistic framing from which $\mathrm{CE}$ management can be undertaken.

Artificial divisions such as those between land and sea, regions/states, the EEZ and Territorial Sea, and activities/management authorities operating in the same physical space create jurisdictional boundaries that can be challenging, but not impossible to work around when it comes to CE management. The Reef 2050 Plan has achieved some improved coordination in this regard by linking GBRMPA, Queensland, and the Commonwealth (Commonwealth of Australia, 2018). While the Reef 2050 Plan recognises existing spatial boundaries and jurisdictions, it also includes an overarching set of principles and strategic approaches to assessing environmental health (e.g., the zone of influence approach) that support collective buy-in and responsibility both within and beyond these boundaries (Commonwealth of Australia, 2018). Through a long process of education, pressure, negotiation and compromise, GBRMPA has now been granted a substantial amount of authority to oversee the implementation of the Reef 2050 Plan, but how this works in practice (including questions related to funding, monitoring, and enforcement) will require further study, as efforts have only just begun.

Another approach to linking across scales in complex coupled human-environmental systems relies on models to simulate the interactions between the multitude of interacting subsystems (e.g., geophysical, ecological, climatological, social, political, economic, cultural). This type of model is rare, and generally heuristic in nature. Such heuristic whole-of-systems models are much better suited (and often developed) to improve understanding of the interactions within complex human-environmental systems rather than for use in management applications (Kelly et al., 2013; Allison et al., 2018). The use of DPSIR models in the context of the GBRMP is an example of a heuristic model that aims to enable managers to make better, more informed decisions about if, where and how activities under their control should take place, however these approaches are much more successful when applied at management-relevant local scales.

In recognising the complexities involved in cross-scale interactions, the door has been opened for the development of tools to assess how and what types of uncertainty are likely to affect environmental management outcomes. Examples include qualitative models (Anthony et al., 2013; Raoux et al., 2018), Bayesian belief networks (Mantyka-Pringle et al., 2017) and models (Schmelter et al., 2012), management strategy evaluations (Nuno et al., 2014), sensitivity analyses (Perz et al., 2013; Stock and Micheli, 2016), and Monte Carlo simulations (Stelzenmüller et al., 2018). These tools can be used to rank management decisions based on the likelihood that the intended results will be achieved given existing uncertainty. 
Transparently assessing uncertainty is necessary for successfully implementing CE assessments, ecosystem-based management, adaptive management principles (Holling, 1973), and the precautionary approach. Tools, techniques and models are also needed to improve practices for assessing and managing $\mathrm{CE}$ (Clarke et al., 2016; Davies et al., 2018a). While there is no universally accepted framework, there are a number of tools to assess cumulative impacts, for example, carrying capacity analysis, impact or interaction matrices, modelling and expert opinion (Walker and Johnston, 1999; Natural England, 2014). However, each of these methods need to be developed and tested with a view to implementing them in line with CE management and decision-making processes (Halpern et al., 2008), which generally requires a substantial investment in collaborative and participatory processes to ground model development in the realities of practice (Voinov et al., 2018). If combined with efforts to take adequate time to collate and analyse existing data sets, this area of work holds great promise. Both case studies are testing the boundaries of how these relationships are established and maintained.

\section{Political Action}

Although positive gains in terms of CE management may be attained through more localised and/or clustered efforts, an overarching policy to guide management activities and plans has long been considered the most straight forward way to rescue both sides of the Tasman Sea from ongoing challenges associated with fragmented legislative regimes; incomplete/inadequate ecological and social, political, economic and cultural data; and competition among stakeholders and Indigenous groups for scarce resources and power over decision-making processes. Despite historical attempts, both Australia and Aotearoa NZ have failed to pass an overarching oceans policy. Australia released an Oceans Policy in 1998 but was unsuccessful in its attempts to institute integrated policymaking (Vince, 2008) and EBM (Tsamenyi and Kenchington, 2012). Aotearoa NZ's oceans policy process came to a halt in 2003 after a significant effort of public consultation, including 71 hui and other meetings. The process was briefly restarted in 2005 but the political will that was driving the earlier effort had been lost with a change of government and priorities (McGinnis, 2012). The passage of the Reef 2050 Plan is a big step forward for GBRMP but is still only applicable to the particulars of the case study area.

A crucial subset of any ocean policy must address the rights of Indigenous peoples. In Aotearoa NZ, Treaty agreements and subsequent legislation provide some guidelines and protections regarding how co-management and co-governance practices should unfold, but in the GBRMP context, there is less of a unifying approach to involving the Traditional Owners of (sea) country than in Aotearoa NZ. The TUMRAs do set a good precedent in some areas (Nursey-Bray and Rist, 2009), but there are deep inequalities associated with TO inclusion in natural resource decision making in Australia in general (Davies et al., 2013; Day and Dobbs, 2013), and this also applies to many parts of GBRMP. The need to recognise TOs as partners, provide support for participation and capacity building and to include values and rights in $\mathrm{CE}$ management and decision-making remains as a gap even under the recently implemented Reef 2050 Plan.

\section{Navigating the Transition}

The transition phase from the current system of CE management and governance to a more adaptive, resilient, and holistic one is likely to be unpredictable and turbulent, and therefore "can only be navigated, not planned" (Olsson et al., 2006, p11 g1). Successful transformations therefore require support from emergent shadow networks; these informal or semi-formal networks facilitate information flows, support social learning, and provide opportunities to experiment with alternative ways of doing governance and management (Schmidt, 2017). They can help to institutionalise the new normal during windows of opportunity, relying on a range of leverage points, including but not limited to economic incentives (Olsson et al., 2006).

Both case studies discussed the emergence of future-focussed, innovative and independent initiatives that brought some optimism to the CE management assembly (Table 3), but the initiatives from the GBRMP case (e.g., Reef Guardian Schools Programme - running since 2003) were relatively wellestablished and well-resourced in comparison with the Aotearoa NZ initiatives discussed (e.g., Navigating the Implementation Impasse research project - running since 2017). Either way, these efforts inject much-needed novelty into transitions (Chaffin et al., 2016), but the authority and reach of older and better resourced networks will clearly have a bigger impact when it comes to supporting CE management transitions. In Aotearoa $\mathrm{NZ}$, the lack of shadow networks addressing CE management and governance has meant that changes tend to be fairly slow - approaches to CE assessment and management have thus far relied primarily on case law related to resource decisions made through the courts (Milne, 2008) and regional efforts by councils or community groups. Most efforts have yet to connect across scales.

Another strategy exhibited in both case studies that can be associated with the emergence of shadow networks is a commitment to participatory processes. Both case studies have leaned on participatory processes in a range of forms and forums to overcome some activity or rights-based conflicts and develop more collective identities and partnerships across vested interests. While there are some promising results arising from these efforts (e.g., the passing of the Reef 2050 Plan in the GBRMP case), the institutional structures, funding mechanisms, and social and cultural changes that are needed to support these developments long-term are still emerging.

Emerging leadership is also important in terms of supporting and maintaining CE governance and management transitions, especially in the institutionalisation of the "new normal." Leadership at GBRMPA has been highlighted for connecting with different sectors, reducing conflict, and spanning scales (Olsson et al., 2008). Strategies initiated by GBRMPA enabled the coordination of the scientific community, increased public awareness of environmental issues and problems, involved a broader set of stakeholders, and maneuvered the political system for support at critical times (Olsson et al., 2008). These efforts 
have enabled the organisation to build interagency and multiscalar support and have set a good precedent for the work that lies ahead in terms of implementing the Reef 2050 Plan.

\section{CONCLUSION}

By comparing Trans-Tasman cumulative effects management challenges and successes and considering these efforts against a transformative governance framework (Olsson et al., 2006), this paper has illuminated several features that are needed to enable effective CE management. The three key challenges associated with the implementation of improved CE management that are considered in this paper are: (1) fragmented legislative regimes; (2) a lack of standardised, long-term ecological-scale data; and (3) poor integration of socio-economic and cultural values, and Indigenous rights into management decision making. This paper addresses these challenges by drawing conclusions and identifying priority actions regarding how to mobilise resources and political will to address $\mathrm{CE}$, how to deal with data scarcity and uncertainty, and how to promote comprehensive and inclusive CE management of coastal and marine areas. We believe these findings provide an important resource for future efforts to implement effective cross-scale CE management in Aotearoa $\mathrm{NZ}$ and GBR/Australia, while also being applicable to other international work on CE management.

\section{Mobilising Resources and Political Will}

To implement effective CE management, there is an urgent need to mobilise diverse actors across scales, interests, institutions and cultures and promote collective actions. This research has revealed some key components that can help or hinder these efforts. First, having a uniting feature or notable value that is impacted by CE can mobilise leadership and generate action. In the case of the GBRMP, the reef itself is a distinct, charismatic feature which is internationally valued, and impacts of bleaching and cyclone damage are typically broadcast widely, encouraging motivated and innovative leaders to emerge from a range of networks to address an identifiable unifying cause.

In the Aotearoa NZ context, no clear value is threatened, and CE result in gradual change and shifting baselines. In cases such as this, it can be difficult to develop broad and effective action to address CE. The development of a unifying vision for management that appeals to disparate interest groups and actors across scales is crucial to the achievement of collective action under these circumstances. The identification of locally or regionally valued ecosystems and related social and cultural practices through participatory processes may help to promote this proactive agenda setting. In either case, institutional and individual leadership is needed to ensure that background knowledge and robust networks are in place so that when a window of opportunity emerges (or is created), leaders can act quickly to streamline fragmented legislative regimes in ways that will reduce stressors and ensure no further harm occurs.

Other key elements of successful CE management include investing in Indigenous partnerships and co-governance arrangements, as well as being generally inclusive of a range of partners - not just the most powerful - in order to ensure broader support through collaboratively defined long term plans for $\mathrm{CE}$ management and ecosystem sustainability. Ongoing resourcing and support of participation of diverse membership within interagency and transdisciplinary working groups (e.g., the range of interests represented on the GBRMPA Reef Advisory Committees) can help to ensure that these processes proceed somewhat independent of political whims. Resourcing these efforts may require flexible and creative funding; looking for opportunities to cluster efforts by region or seeking support from both higher and lower scales may help to assemble these resources.

\section{Dealing With Data Scarcity and Uncertainty}

Addressing data scarcity and high levels of uncertainty in the context of $\mathrm{CE}$ governance and management is a notoriously difficult task, but in some cases data or information may exist that can be repurposed for CE management decision making. By partnering with indigenous and local knowledge holders, whose knowledge of an area may go back decades or even generations, it may be possible to gain some of the long-term data needed to improve CE management and decision making. Mining existing data sets for $\mathrm{CE}$ data may also prove to be a valuable option. Although most of these data sets are unlikely to be appropriate for use across large scales, they may be useful for local and/or regional CE management purposes.

In addition to promoting better use of existing data, it is important to collect new data to help reduce uncertainties where possible. Today the GBRMP has over 90 monitoring programms operating at a variety of spatial and temporal scales (Reef 2050 IMRP, 2018). Comprehensive, strategic social-ecological system assessments can provide a scientific baseline from which policy can evaluate ongoing changes to determine whether action is required to halt degradation; these kinds of assessments also provide clarity around the suite of social, cultural, and economic system components that should be included in $\mathrm{CE}$ assessments. Additionally, the DPSIR model is now being used by the GBRMPA as a unifying framework to describe integrated monitoring and management of the GBRMP. This EBM approach is designed to allow managers to understand connections between components of and processes acting upon the GBRMP to facilitate integrated monitoring and management. The choice of model is arguably not as important as its ability to provide a cohesive metaphor that transparently links human-nature interactions and types of knowledge and information for decision making purposes.

\section{Promoting Comprehensive and Inclusive CE Management of Coastal and Marine Areas}

Effective CE management must be based on holistic systemsbased thinking that incorporates cross-scale interactions [e.g., ki uta ki tai (mountain to sea)], incorporates the multitude of overlapping, synergistic and antagonistic human and natural impacts, and accounts for the values and rights of current and future generations. A number of tactics support systems-based 
thinking/acting, though these approaches are often contrary to existing conventional sector-based management and statutory regulations. For example, principles-based approaches such as those included in the Reef 2050 Plan and under development in the Aotearoa NZ context (Davies et al., 2019) provide a set of guidelines for CE management without being too prescriptive. Inter- and transdisciplinary research efforts also tend to enable holistic, interconnected approaches to problem resolution, rather than focusing on prescriptive limit setting for individual stressors (as these approaches tend to ignore synergistic or antagonistic interactions). While these approaches come with their own challenges, they are far better suited to CE management than anything that has yet been attempted.

\section{Priority Actions}

This research indicates that collaborative approaches can generally improve the implementation and practice of $\mathrm{CE}$ management, but further prioritisation is needed to guide future efforts. The following priority actions are envisioned as being deployed in advance of a crisis; once a crisis is identified as occurring, circumstances may dictate that another sequence of events is needed. To improve CE management practices, we recommend that future work on $\mathrm{CE}$ :

(1) Establish inclusive, transparent, well-resourced processes that support on-going partnerships across institutions and scales. In particular, this includes investing in Indigenous partnerships and co-governance arrangements.

(2) Develop a unifying vision for CE management that can connect disparate interest groups and actors across scales. Identifying locally or regionally valued ecosystems and related social and cultural practices that can be connected to larger scales may help with this process.

(3) Develop collaborative, cross-scale, principles-based approaches that can provide a holistic suite of guidelines for CE management and ensuing CE assessment.

(4) Analyse existing methods, tools and data to identify and assess $\mathrm{CE}$ over the long term, including Indigenous and local knowledge and other SPEC data sets. Conceptual models, risk assessments, and gap analyses may be needed to help identify sources of uncertainty and their importance in decision making. Where there are data gaps, establish monitoring regimes that are inclusive of relevant social-ecological indicators.

(5) Implement contextualised, system-based, coordinated and adaptive principles-based approaches to CE. These programs should be evaluated against the principles and visions established through partnership approaches.

\section{REFERENCES}

Ainsworth, T. D., Heron, S. F., Ortiz, J. C., Mumby, P. J., Grech, A., Ogawa, D., et al. (2016). Climate change disables coral bleaching protection on the Great Barrier Reef. Science 352, 338-342. doi: 10.1126/science.aac 7125

Allison, A. E. F., Dickson, M. E., Fisher, K. T., and Thrush, S. F. (2018). Dilemmas of modelling and decision-making in environmental

\section{DATA AVAILABILITY STATEMENT}

The datasets for this study will not be made publicly available because some data was obtained in confidence and therefore cannot be shared publicly. Identifiers have been removed from the data and key points and themes are included in the tables provided for publication.

\section{ETHICS STATEMENT}

This study was carried out in accordance with the recommendations and protocol approval of the NIWA Human Research Approval Process with oral and/or written informed consent from all subjects.

\section{AUTHOR CONTRIBUTIONS}

$\mathrm{KD}, \mathrm{KF}, \mathrm{GC}$, and IP contributed to the conception, design and implementation of the research. $\mathrm{KD}, \mathrm{KF}$, and AA performed the initial data analysis, developed the tables and figures, and drafted the manuscript. GC, IP, JD, MF, and CL contributed to the interpretation of results, wrote sections of the manuscript, and provided critical revisions to the intellectual content of the manuscript. All authors contributed to manuscript revision, read and approved the submitted version.

\section{FUNDING}

Funding for this research was provided by Ministry of Business, Innovation and Employment research contracts C01X1515 (Sustainable Seas) through NIWA Project Number SUSS18201 (Navigating the implementation impasse: enabling interagency collaboration on cumulative effects) and the Strategic Science Investment Fund NIWA research contract COME1903. Additional funding to support this work was provided by the New Zealand Coastal Society's Professional Development Award.

\section{ACKNOWLEDGMENTS}

We would like to thank the focus group and workshop participants for their contributions to this research.

research. Environ. Model. Softw. 99, 147-155. doi: 10.1016/j.envsoft.2017.0 9.015

Anthony, K. R., Dambacher, J. M., Walshe, T. R., and And Beeden, R. (2013). A Framework for Understanding Cumulative Impacts, Supporting Environmental Decisions and Informing Resilience Based Management of the Great Barrier Reef World Heritage Area: Final Report to the Great Barrier Reef Marine Park Authority and Department of the Environment. Townsville: Australian Institute of Marine Science. 
Arkema, K. K., Abramson, S. C., and Dewsbury, B. M. (2006). Marine ecosystembased management: from characterization to implementation. Front. Ecol. Environ. 4, 525-532. doi: 10.1890/1540-929520064[525:MEMFCT]2.0.CO;2

Auckland Council (2016). Auckland Unitary Plan (Operative in part), $\$ F$ Coastal. Auckland: Auckland Council.

Australian Government (2018). Reef 2050 Policies on Providing Net Benefits and Managing Cumulative Impacts. Available at: http://www.gbrmpa.gov.au/ourwork/reef-strategies/Reef-2050-policies

Bay of Plenty Regional Council (2011). Regional Coastal Environment Plan, Environmental Publication 2003/08 - ISSN 1175-9372. Tauranga: Bay of Plenty Regional Council.

Bess, R. (2010). Maintaining a balance between resource utilisation and protection of the marine environment in New Zealand. Mar. Policy 34, 690-698. doi: 10.1016/j.marpol.2010.01.001

Brake, L., and Peart, R. (2015). Sustainable Seas: Managing the Marine Environment. Auckland: Environmental Defence Society Incorporated.

Bremer, S., and Glavovic, B. (2013). Exploring the science-policy interface for integrated coastal management in New Zealand. Ocean Coast. Manag. 84, 107-118. doi: 10.1016/j.ocecoaman.2013.08.008

Bryan, M. (2017). Valuing scared tribal waters within prior appropriation. Nat. Resour. J. 57, 139-181.

Burkepile, D. E., and Hay, M. E. (2006). Herbivore vs. nutrient control of marine primary producers: context-dependent effects. Ecology 87, 3128-3139. doi: 10.1890/0012-9658(2006)87\%5B3128:hvncom\%5D2.0.co;2

Canter, L., and Ross, B. (2010). State of practice of cumulative effects assessment and management: the good, the bad and the ugly. Impact Assess. Project Apprais. 28, 261-268. doi: 10.3152/146155110x12838715793200

Chaffin, B. C., Garmestani, A. S., Gunderson, L. H., Melinda, B. H., Angeler, D. G., Tony, C. A., et al. (2016). Transformative environmental governance. Ann. Rev. Environ. Resour. 41, 399-423.

Charmaz, K. (2014). Constructing Grounded Theory. Thousand Oaks: Sage.

Clapcott, J., Ataria, J., Hepburn, C., Hikuroa, D., Jackson, A.-M., Kirikiri, R., et al. (2018). Mātauranga Māori: shaping marine and freshwater futures. N. Zeal. J. Mar. Freshw. Res. 51, 457-466. doi: 10.1080/00288330.2018.1539404

Clarke, D., Goodwin, E., Sinner, J., Ellis, J., and Singh, G. (2016). Validation and limitations of a cumulative impact model for an estuary. Ocean Coast. Manag. 120, 88-98. doi: 10.1016/j.ocecoaman.2015.11.013

Collins, S. L., Swinton, S. M., Anderson, C. W., Benson, B. J., Brunt, J., Gragson, T., et al. (2007). Integrated Science for Society and the Environment: A Strategic Research Initiative. Albuquerque, NM: LTER Network Office.

Commonwealth of Australia (2018). Reef 2050 Long-Term Sustainability Plan - July 2018 Reef 2050 Plan. Available at: www.environment.gov.au/marine/ gbr/long-term-sustainability-plan (accessed February 11, 2020).

Cormier, R., Kelble, C. R., Anderson, M. R., Allen, J. I., Grehan, A., and Gregersen, O. (2017). Food for thought: moving from ecosystem-based policy objectives to operational implementation of ecosystem-based management measures. ICES J. Mar. Sci. 74, 406-413. doi: 10.1093/icesjms/fsw181

Crain, C. M., Kroeker, K., and Halpern, B. S. (2008). Interactive and cumulative effects of multiple human stressors in marine systems. Ecol. Lett. 11, 1304-1315. doi: 10.1111/j.1461-0248.2008.01253.x

Crease, R. P., Le Heron, E., Fisher, K. T., and Davies, K. K. (2019). How can collaboration improve cumulative effects management practices? N. Zeal. Resour. Manag. J. 29-34.

Cumming, G., Cumming, D., and Redman, C. (2006). Scale mismatches in social-ecological systems: causes, consequences and solutions. Ecol. Soc. $11: 14$.

Dale, A., George, M., Hill, R., and Fraser, D. (2016). Traditional Owners and Sea Country in the Southern Great Barrier Reef - Which Way Forward? Report to the National Environmental Science Program. Kenner, LA: Reef and Rainforest Research Centre Ltd.

Davies, J., Hill, R., Walsh, F. J., Sandford, M., Smyth, D., and Holmes, M. C. (2013). Innovation in management plans for community conserved areas: experiences from Australian indigenous protected areas. Ecol. Soc. 18:14. doi: 10.5751/ES05404- 180214

Davies, K., Fisher, K., Foley, M., Greenaway, A., Hewitt, J., Le Heron, R., et al. (2018a). Navigating collaborative networks and cumulative effects for Sustainable Seas. Environm. Sci. Policy. 83, 22-32. doi: 10.1016/j.envsci.2018. 01.013
Davies, K., Murchie, A., Kerr, V., and Lundquist, C. (2018b). The evolution of marine protected area planning in Aotearoa New Zealand: reflections on participation and process. Mar. Policy. 93, 113-127. doi: 10.1016/j.marpol.2018. 03.025

Davies, K. K., Couzens, G., Fisher, K., Faulkner, L., and Hewitt, J. (2019). Principles for cumulative effects management in Aotearoa New Zealand. N. Zeal. Resour. Manag. J. 11-15.

Day, J. C., and Dobbs, K. (2013). Effective governance of a large and complex crossjurisdictional marine protected area: Australia's Great Barrier Reef. Mar. Policy 41, 14-24. doi: 10.1016/j.marpol.2012.12.020

De Valck, J., and Rolfe, J. (2018). Linking water quality impacts and benefits of ecosystem services in the Great Barrier Reef. Mar. Pollut. Bull. 130, 55-66. doi: 10.1016/j.marpolbul.2018.03.017

De'ath, G., Fabricius, K. E., Sweatman, H., and Puotinen, M. (2012). The 27-year decline of coral cover on the Great Barrier Reef and its causes. Proc. Natl. Acad. Sci. U.S.A. 109, 17995-17999. doi: 10.1073/pnas.1208909109

Department of Conservation (2000). The New Zealand Biodiversity Strategy 20002020. Wellington: Department of Conservation.

Department of Conservation (2010). New Zealand Coastal Policy Statement 2010. Wellington: Department of Conservation.

Department of Conservation (2017). Review of the Effect of the NZCPS 2010 on RMA Decision Making. Jefferson City, MO: Department of Conservation.

Dye v Auckland Regional Council (2002). 1 New Zealand Law Review 337.

Environment Southland (2013). Regional Coastal Plan for Southland. Invercargill: Environment Southland.

Evans, N. (2011). More than a Sign on the Fence? Teacher Learning and the Reef Guardian Schools Program in Far North Queensland. Saarbrücken: VDM Verlag Dr. Müller.

Fanning, L., Mahon, R., McConney, P., Angulo, J., Burrows, F., Chakalall, B., et al. (2007). A large marine ecosystem governance framework. Mar. Policy 31, 434-443. doi: 10.1016/j.marpol.2007.01.003

Foley, M. M., Mease, L. A., Martone, R. G., Prahler, E. E., Morrison, T. H., Clarke Murray, C., et al. (2017). The challenges and opportunities in cumulative effects assessment. Environ. Impact Assess. Rev. 62, 122-134. doi: 10.1016/j.eiar.2016. 06.008

Folke, C., Carpenter, S. R., Walker, B., Scheffer, M., Chapin, T., and Rockström, J. (2010). Resilience thinking: integrating resilience, adaptability and transformability. Ecol. Soc. 15, 20.

Folke, C., Hahn, T., Olsson, P., and Norberg, J. (2005). Adaptive governance of social-ecological knowledge. Ann. Rev. Environ. Resour. 30, 441-473.

Fontana, A., and Frey, J. H. (1998). "Interviewing: the art of science," in Collecting and Interpreting Qualitative Materials, eds N. K. Denzin, and Y. S. Lincoln (Thousand Oaks, CA: Sage Publications, Inc).

Fraser, G., Rohde, K., and Silburn, M. (2017). Fertiliser management effects on dissolved inorganic nitrogen in runoff from Australian sugarcane farms. Environ. Monit. Assess. 189, 409. doi: 10.1007/s10661-017-6115-Z

Fuentes, M. M. P. B., Limpus, C. J., and Hamann, M. (2011). Vulnerability of sea turtle nesting grounds to climate change. Glob. Change Biol. 17, 140-153. doi: 10.1111/j.1365-2486.2010.02192.x

Gelcich, S., Reyes-Mendy, F., Arriagada, R., and Castillo, B. (2018). Assessing the implementation of marine ecosystem based management into national policies: insights from agenda setting, and policy responses. Mar. Policy. 92, 40-47. doi: 10.1016/j.marpol.2018.01.017

Goldberg, J., Marshall, N., Birtles, A., Case, P., Bohensky, E., Curnock, M., et al. (2016). Climate change, the Great Barrier Reef and the response of Australians. Palgrave Commun. 2:15046.

Great Barrier Reef Marine Park Authority (2014a). Great Barrier Reef Outlook Report 2014. Townsville: GBRMPA.

Great Barrier Reef Marine Park Authority (2014b). Great Barrier Reef Region Strategic Assessment: Strategic Assessment Report. Townsville: GBRMPA.

Great Barrier Reef Marine Park Authority (2017). Great Barrier Reef Blueprint for Resilience. Townsville: GBRMPA.

Great Barrier Reef Marine Park Authority (2018a). Cumulative Impact Management Policy. Townsville: GBRMPA.

Great Barrier Reef Marine Park Authority (2018b). Good Practice Management for the Great Barrier Reef. Townsville: GBRMPA.

Great Barrier Reef Marine Park Authority (2018c). Net Benefit Policy. Townsville: GBRMPA. 
Great Barrier Reef Marine Park Authority, and Queensland Government (2018). Reef 2050 Integrated Monitoring and Reporting Program Strategy Update 2018 Reef 2050 IMRP. Julago: Great Barrier Reef Marine Park Authority.

Guerrero, A., McAllister, R., Corcoran, J., and Wilson, K. (2013). Scale mismatches, conservation planning, and the value of social network analysis. Conserv. Biol. 27, 35-44. doi: 10.1111/j.1523-1739.2012.01964.x

Halpern, B. S., Frazier, M., Potapenko, J., Casey, K. S., Koenig, K., Longo, C., et al. (2015). Spatial and temporal changes in cumulative human impacts on the world's ocean. Nat. Commun. 6:7615.

Halpern, B. S., and Fujita, R. (2013). Assumptions, challenges, and future directions in cumulative impact analysis. Ecosphere 4:131.

Halpern, B. S., Walbridge, S., Selkoe, K. A., Kappel, C. V., Micheli, F., D’Agrosa, C., et al. (2008). A global map of human impact on marine ecosystems. Science 319, 948-952.

Hardin, G. (1968). The tragedy of the commons. Science 162, 1243-1248.

Harmsworth, G., and Awatere, S. (2013). "Indigenous Māori knowledge and perspectives of ecosystems," in Ecosystem Services in New Zealand: Conditions and Trends, ed. J. Dymond (Lincoln: Manaaki Whenua Press), 274-286.

Harmsworth, G., Awatere, S., and Robb, M. (2016). Indigenous Māori values and perspectives to inform freshwater management in Aotearoa-New Zealand. Ecol. Soc. 21:9.

Harvey, B. P., Gwynn-Jones, D., and Moore, P. J. (2013). Meta-analysis reveals complex marine biological responses to the interactive effects of ocean acidification and warming. Ecol. Evol. 4, 1016-1030. doi: 10.1002/ece3.516

Hassan, D., and Alam, A. (2019). Marine spatial planning and the Great Barrier Reef Marine Park Act 1975: an evaluation. Ocean Coast. Manag. 167, 188-196. doi: 10.1016/j.ocecoaman.2018.10.015

Henwood, W., and Henwood, R. (2011). Mana Whenua Kaitiakitanga in action: restoring the mauri of lake ōmāpere. Alternative 7, 220-232. doi: 10.1177/ 117718011100700303

Hewitt, J., Faulkner, L., Greenaway, A., and Lundquist, C. (2018). Proposed ecosystem-based managment principles for New Zealand. Resour. Manag. J. $10-13$.

Holling, C. S. (1973). Resilience and stability of ecological systems. Ann. Rev. Ecol. Syst. 4, 1-23. doi: 10.1146/annurev.es.04.110173.000245

Irvine, K. N., Warber, S. L., Devine-Wright, P., and Gaston, K. J. (2013). Understanding urban green space as a health resource: a qualitative comparison of visit motivation and derived effects among park users in sheffield, UK. Int. J. Environ. Res. Public Health 10, 417-442. doi: 10.3390/ijerph100 10417

Jackson, A. M., Hepburn, C., and Flack, B. (2018). East Otago Taiāpure: sharing the underlying philosophies 26 years on. N. Zeal. J. Mar. Freshw. Res. 52, 577-589. doi: 10.1080/00288330.2018.1536066

Jackson, S. (2018). Building trust and establishing legitimacy across scientific, water management and Indigenous cultures. Austr. J. Water Resour. 23, 1-10. doi: 10.1080/13241583.2018.1505994

Jann, W., and Wegrich, K. (2007). "Theories of the policy cycle," in Handbook of Public Policy Analysis: Theory, Politics, and Methods, eds F. Fischer, G. Miller, and M. S. Sidney (Boca Raton: Taylor \& Francis).

Jollands, N., and Harmsworth, G. (2007). Participation of indigenous groups in sustainable development monitoring: rationale and examples from New Zealand. J. Int. Soc. Ecol. Econ. 63, 716-726. doi: 10.1016/j.ecolecon.2006. 09.010

Jones, A. R., Doubleday, Z. A., Prowse, T. A. A., Wiltshire, K. H., Deveney, M. R., Ward, T., et al. (2018). Capturing expert uncertainty in spatial cumulative impact assessments. Sci. Rep. 8:1469. doi: 10.1038/s41598-018-19354-6

Joseph, R., Rakena, M., Te Kuini Jones, M., Sterling, R., and Rakena, C. (2018). The Treaty, Tikanga Māori, Ecosystem-Based Management, Mainstream Law and Power Sharing for Environmental Integrity in Aotearoa New Zealand-Possible Ways Forward. Available at: https://sustainableseaschallenge.co.nz/newsupdates/empowering-maori-improve-ecosystem-management-aotearoa (accessed February 11, 2020).

Kainamu-Murchie, A., Marsden, I., Tau, R., Gaw, S., and Pirker, J. (2018). Indigenous and local peoples' values of estuarine shellfisheries: moving towards holistic-based catchment management. N. Zeal. J. Mar. Freshw. Res. 52, 526541. doi: 10.1080/00288330.2018.1523200

Kelly, R. A., Jakeman, A. J., Barreteau, O., Bursuk, M. E., Elsawah, S., Hamilton, S. H., et al. (2013). Selecting among five common modelling approaches for integrated environmental assessment and management. Environ. Model. Softw. 47, 159-181. doi: 10.1016/j.envsoft.2013.05.005

Kingdon, J. W. (1995). Agendas, Alternatives, and Public Policies. New York, NY: Harper Collins.

Korpinen, S., and Andersen, J. H. (2016). A global review of cumulative pressure and impact assessments in marine environments. Front. Mar. Sci. 3:153. doi: 10.3389/fmars.2016.00153

Le Heron, R., Lewis, N., Fisher, K., Thrush, S., Lundquist, C., Hewitt, J., et al. (2016). Non-sectarian scenario experiments in socio-ecological knowledge building for multi-use marine environments: insights from New Zealand's Marine Futures project. Mar. Policy 67, 10-21. doi: 10.1016/j.marpol.2016.01.022

Lewison, R. L., Rudd, M. A., Al-Hayek, W., Baldwin, C., Beger, M., Lieske, S. N., et al. (2016). How the DPSIR framework can be used for structuring problems and facilitating empirical research in coastal systems. Environ. Sci. Policy 56, 110-119. doi: 10.1016/j.envsci.2015.11.001

Ludwig, D., Hilborn, R., and Walters, C. (1993). Uncertainty, resource exploitation, and conservation: lessons from history. Ecological Applications. 260, 17-36. doi: $10.1126 /$ science. 260.5104 .17

Lundquist, C., Fisher, K. T., Le Heron, R., Lewis, N. I., Ellis, J. I., Hewitt, J. E., et al. (2016). Science and societal partnerships to address cumulative impacts. Front. Mar. Sci. 3:2. doi: 10.3389/fmars.2016.00002

MacDiarmid, A., McKenzie, A., Sturman, J., Beaumont, J., Mikaloff-Fletcher, S., and Dunne, J. (2012). Assessment of Anthropogenic Threats to New Zealand Marine Habitats (New Zealand Aquatic Environment and Biodiversity Report No. 93). Auckland: NIWA.

Mach, M., Reiter, S., and Good, L. H. (2015). Managing a mess of cumulative effects: linking Science and policy to create solutions. J. Mar. Educ. 29, 26-31.

Mantyka-Pringle, C. S., Jardine, T. D., Bradford, L., Bharadwaj, L., Kythreotis, A. P., Fresque-Baxter, J., et al. (2017). Bridging science and traditional knowledge to assess cumulative impacts of stressors on ecosystem health. Environ. Int. 102, 125-137. doi: 10.1016/j.envint.2017.02.008

Marlborough District Council (2011). Marlborough Sounds Resource Management Plan (Proposed). Blenheim: Marlborough District Council.

Marshall, N., Adger, W. N., Benham, C., Brown, K., Curnock, M. I., Gurney, G. G., et al. (2019). Reef Grief: investigating the relationship between place meanings and place change on the Great Barrier Reef. Austr. Sustain. Sci. 14:579. doi: 10.1007/s11625-019-00666-z

Marshall, N. A., Bohensky, E., Curnoch, M., Goldberg, J., Gooch, M., Pert, P. L., et al. (2013). A Social and Economic Long Term Monitoring Program for the Great Barrier Reef. Key Findings 2013 Report to the National Environmental Research Program. Cairns: Reef and Rainforest Research Centre Limited.

McCook, L. (1999). Macroalgae, nutrients and phase shifts on coral reefs: scientific issues and management consequences for the Great Barrier Reef. Coral Reefs 18, 357-367. doi: 10.1007/s003380050213

McGinnis, M. V. (2012). Ocean Governance: The New Zealand Dimension. A Full Report. Emerging Issues Programme. School of Government. Wellington: Victoria University of Wellington.

McKinley, E., and Fletcher, S. (2012). Improving marine environmental health through marine citizenship: a call for debate. Mar. Policy 36, 839-843. doi: 10.1016/j.marpol.2011.11.001

McLeod, K., Lubchenco, J., Palumbi, S. R., and Rosenberg, A. A. (2005). Scientific Consensus Statement on Marine Ecosystem-Based Management. New York, NY: Duke University Press.

Milne, P. (2008). When is enough, enough? Dealing with cumulative effects under the resource management act. PLoS One 8:e79889.

Ministry for the Environment \& Statistics NZ. (2015). New Zealand's Environmental Reporting Series: Environment Aotearoa 2015. Wellington: Ministry for the Environment.

Ministry for the Environment \& Statistics NZ. (2016). New Zealand's Environmental Reporting Series, Our Marine Environment 2016. Wellington: Ministry for the Environment.

Ministry for the Environment [MfE] (1991). Resource Management Act. Wellington: Ministry for the Environment.

Ministry for the Environment [MfE] (2012). Exclusive Economic Zone and Continental Shelf (Environmental Effects) Act (EEZ Act). Wellington: Ministry for the Environment.

Ministry for the Environment [MfE] (2015). Environmental Reporting Act. Wellington: Ministry for the Environment. 
Murray, C. C., Mach, M., and Martone, R. G. (2014). Cumulative Effects in Marine Ecosystems: Scientific Perspectives on its Challenges and Solutions. New York, NY: WWF-Canada and Center For Ocean Solutions.

Mutu, M. (2012). “The sea I never gave: fisheries settlement," in Treaty of Waitangi Settlements, eds N. R. Wheen, and J. Hayward (Wellington: Bridget Williams Books).

Natural England (2014). Development of a Generic Framework for Informing Cumulative Impact Assessments (CIA) Related to Marine Protected Areas through Evaluation of Best Practice (NECR147). New York, NY: Natural England.

Nuno, A., Bunnefeld, N., and Milner-Gulland, E. J. (2014). Managing socialecological systems under uncertainty: implementation in the real world. Ecol. Soc. 19:52.

Nursey-Bray, M., and Rist, P. (2009). Co-management and protected area management: achieving effective management of a contested site, lessons from the Great Barrier Reef World Heritage Area (GBRWHA). Mar. Policy 33, 118-127. doi: 10.1016/j.marpol.2008.05.002

Nyumba, T. O., Wilson, K., Derrick, C. J., and Mukherjee, N. (2018). The use of focus group discussion methodology: insights from two decades of application in conservation. Methods Ecol. Evol. 9, 20-32. doi: 10.1111/2041-210X.12860

Okura Holdings Limited v Auckland City Council (2018). New Zealand Environment Court, NZEnvC. 87.

Olsson, P., Folke, C., and Hughes, T. P. (2008). Navigating the transition to ecosystem-based management of the Great Barrier Reef, Australia. Proc. Natl. Acad. Sci. U.S.A. 105, 9489-9494. doi: 10.1073/pnas.0706905105

Olsson, P., Gunderson, L. H., Carpenter, S. R., Ryan, P., Lebel, L., Folke, C., et al. (2006). Shooting the rapids: navigating transitions to adaptive governance of social-ecological systems. Ecol. Soc. 11:18.

Ortiz, J.-C., Wolff, N. H., Anthony, K. R. N., Devlin, M., Lewis, S., and Mumby, P. J. (2018). Impaired recovery of the Great Barrier Reef under cumulative stress. Sci. Adv. 4:eaar6127. doi: 10.1126/sciadv.aar6127

Patrício, J., Elliott, M., Mazik, K., Papadopoulou, K. N., and Smith, C. J. (2016). DPSIR - two decades of trying to develop a unifying framework for marine environmental management? Front. Mar. Sci. 3:177. doi: 10.3389/fmars.2016. 00177

Perz, S. G., Muñoz-Carpena, R., Kiker, G., and Holt, R. (2013). Evaluating ecological resilience with global sensitivity and uncertainty analysis. Ecol. Model. 263, 174-186. doi: 10.1016/j.ecolmodel.2013.04.024

Post, L. A., Raile, A. N. W., and Raile, E. D. (2010). Defining political will. Polit. Policy 38, 653-676. doi: 10.1111/j.1747-1346.2010.00253.x

Przeslawski, R., Byrne, M., and Mellin, C. (2015). A review and meta-analysis of the effects of multiple abiotic stressors on marine embryos and larvae. Glob. Change Biol. 21, 2122-2140. doi: 10.1111/gcb.12833

Ralls, K., and Taylor, B. L. (2000). Better policy and management decisions through explicit analysis of uncertainty: new approaches for marine conservation. Conserv. Biol. 14, 1240-1242. doi: 10.1046/j.1523-1739.2000.99408.x

Raoux, A., Dambacher, J. M., Pezy, J. P., Mazé, C., Dauvin, J. C., and Niquil, N. (2018). Assessing cumulative socio-ecological impacts of offshore wind farm development in the Bay of Seine (English Channel). Mar. Policy 89, 11-20. doi: 10.1016/j.marpol.2017.12.007

RJ Davidson Family Trust v Marlborough District Council (2016). The Environment Court, NZEnvC. 81.

RJ Davidson Family Trust v Marlborough District Council (2017). The High Court, NZRMA. 227.

Ruru, J. (2018). Listening to Papatûānuku: a call to reform water law. J. R. Soc. N. Zeal. 48, 215-224. doi: 10.1080/03036758.2018.1442358

Sander, G. (2018). Ecosystem-based management in Canada and Norway: the importance of political leadership and effective decision-making for implementation. Ocean Coast. Manag. 163, 485-497. doi: 10.1016/j.ocecoaman. 2018.08.005

Schiel, D. R., and Howard-Williams, C. (2016). Controlling inputs from the land to sea: limit-setting, cumulative impacts and ki uta ki tai. Mar. Freshw. Res. 67, 57-64.

Schmelter, M. L., Erwin, S. O., and Wilcock, P. R. (2012). Accounting for uncertainty in cumulative sediment transport using Bayesian statistics. Geomorphology 175, 1-13. doi: 10.1016/j.geomorph.2012.06.012

Schmidt, J. J. (2017). Social learning in the Anthropocene: novel challenges, shadow networks, and ethical practices. J. Environ. Manage 193, 373-380. doi: 10.1016/ j.jenvman.2017.02.043
Severinsen, G., and Peart, R. (2018). Reform of the Resource Management System. The Next Generation. Synthesis Report. Auckland: Environmental Defence Society.

Sheaves, M., Coles, R., Dale, P., Grech, A., Pressey, R. L., and Waltham, N. J. (2016). Enhancing the value and validity of EIA: serious science to protect Australia's Great Barrier Reef. Conserv. Lett. 9, 377-383. doi: 10.1111/conl.12219

Stelzenmüller, V., Coll, M., Mazaris, A. D., Giakoumi, S., Katsanevakis, S., Portman, M. E., et al. (2018). A risk-based approach to cumulative effect assessments for marine management. Sci. Total Environ. 612, 1132-1140. doi: 10.1016/j. scitotenv.2017.08.289

Stock, A., and Micheli, F. (2016). Effects of model assumptions and data quality on spatial cumulative human impact assessments. Glob. Ecol. Biogeogr. 25, 1321-1332. doi: 10.1111/geb.12493

Strauss, A. L., and Corbin, J. M. (1990). Basics of Qualitative Research: Grounded Theory Procedures and Techniques. Newbury Park, CA: Sage Publications.

Takala, T., Tikkanen, J., Haapala, A., Pitkänen, S., Torssonen, P., Valkeavirta, R., et al. (2019). Shaping the concept of bioeconomy in participatory projects - An example from the post-graduate education in Finland. J. Clean. Product. 221, 176-188. doi: 10.1016/j.jclepro.2019.02.007

Te Aho, L. (2018). Te Mana o te Wai: an indigenous perspective on rivers and river management. River Res. Appl. 35, 1615-1621. doi: 10.1002/rra.3365

Teddlie, C., and Yu, F. (2007). Mixed methods sampling: a typology with examples. J. Mixed Methods Res. 1, 77-100. doi: 10.1097/SPC.0b013e328358214e

Therivel, R., and Ross, B. (2007). Cumulative effects assessment: does scale matter? Environ. Impact Assess. Rev. 27, 365-385. doi: 10.1016/j.eiar.2007.02.001

Tipa, G., Harmsworth, G., Williams, E., and Kitson, J. (2016). "Integrating mātauranga Māori into freshwater management, planning and decision making," in Advances in New Zealand Freshwater Science, eds P. Jellyman, T. Davie, C. Pearson, and J. Harding (Waco, TX: Limnological Society Inc), 613-632.

Tsamenyi, M., and Kenchington, R. (2012). Australian oceans policymaking. Coast. Manag. 40, 119-132. doi: 10.1080/08920753.2012.652519

Vercelloni, J., Caley, M. J., and Mergersen, K. (2017). Crown-of-thorns starfish undermine the resilience of coral populations on the Great Barrier Reef. Glob. Ecol. Biogeogr. 26, 846-853. doi: 10.1111/geb.12590

Vince, J. (2008). Ten years of implementing Australia's Oceans policy: from an integrated approach to an environmental policy focus. Maritime Eng. 159, 1-10. doi: 10.1080/07266472.2008.10878880

Voinov, A., Jenni, K., Gray, S., Kolagani, N., Glynn, P. D., Bommel, P., et al. (2018). Tools and methods in participatory modeling: selecting the right tool for the job. Environ. Modell. Softw. 109, 232-255. doi: 10.1016/j.envsoft.2018.0 8.028

Walker, L., and Johnston, J. (1999). Guidelines for the Assessment of Indirect and Cumulative Impacts as Well as Impact Interactions (NE80328/D1/3). Available at: http://ec.europa.eu/environment/archives/eia/eia-studies-and-reports/pdf/ guidel.pdf (accessed February 11, 2020).

Webster, K., and Cheyne, C. (2017). Creating treaty-based local governance in New Zealand: Māori and Pākehā views. Kôtuitui 12, 146-164. doi: 10.1080/ 1177083x.2017.1345766

Weeks, R., Pressey, R., Wilson, J., Knight, M., Horigue, V., Abesamis, R., et al. (2015). Ten things to get right for marine conservation planning in the Coral Triangle. F100 Research 3:91. doi: 10.12688/f1000research.3886.3

Wu, P. P.-Y., Fookes, C., Pitchforth, J., and Mergersen, K. (2015). A framework for model integration and holistic modelling of socio-technical systems. Decis. Support Syst. 71, 14-27. doi: 10.1016/j.dss.2015.01.006

Yin, R. K. (2011). Qualitative Research from Start to Finish. New York, NY: Guilford Press.

Conflict of Interest: The authors declare that the research was conducted in the absence of any commercial or financial relationships that could be construed as a potential conflict of interest.

Copyright (c) 2020 Davies, Fisher, Couzens, Allison, van Putten, Dambacher, Foley and Lundquist. This is an open-access article distributed under the terms of the Creative Commons Attribution License (CC BY). The use, distribution or reproduction in other forums is permitted, provided the original author(s) and the copyright owner(s) are credited and that the original publication in this journal is cited, in accordance with accepted academic practice. No use, distribution or reproduction is permitted which does not comply with these terms. 